Prepared in cooperation with the U.S. Department of the Interior Bureau of Land Management; Montana Department of Environmental Quality; Wyoming Department of Environmental Quality; and Wyoming Game and Fish Department

\title{
Assessment of Potential Effects of Water Produced from Coalbed Natural Gas Development on Macroinvertebrate and Algal Communities in the Powder River and Tongue River, Wyoming and Montana, 2010
}

Open-File Report 2011-1294 



\section{Assessment of Potential Effects of Water Produced from Coalbed Natural Gas Development on Macroinvertebrate and Algal Communities in the Powder River and Tongue River, Wyoming and Montana, 2010}

By David A. Peterson, Eric G. Hargett, and David L. Feldman

Prepared in cooperation with the U.S. Department of the Interior Bureau of Land Management; Montana Department of Environmental Quality; Wyoming Department of Environmental Quality; and Wyoming Game and Fish Department

Open-File Report 2011-1294 


\title{
U.S. Department of the Interior \\ KEN SALAZAR, Secretary \\ U.S. Geological Survey \\ Marcia K. McNutt, Director
}

\author{
U.S. Geological Survey, Reston, Virginia: 2011
}

For more information on the USGS - the Federal source for science about the Earth, its natural and living resources, natural hazards, and the environment, visit http://www.usgs.gov or call 1-888-ASK-USGS.

For an overview of USGS information products, including maps, imagery, and publications, visit http://www.usgs.gov/pubprod

Any use of trade, product, or firm names is for descriptive purposes only and does not imply endorsement by the U.S. Government.

Although this report is in the public domain, permission must be secured from the individual copyright owners to reproduce any copyrighted materials contained within this report.

Suggested citation:

Peterson, D.A., Hargett, E.G., and Feldman, D.L., 2011, Assessment of potential effects of water produced from coalbed natural gas development on macroinvertebrate and algal communities in the Powder River and Tongue River, Wyoming and Montana, 2010: U.S. Geological Survey Open-File Report 2011-1294, 34 p. 


\section{Contents}

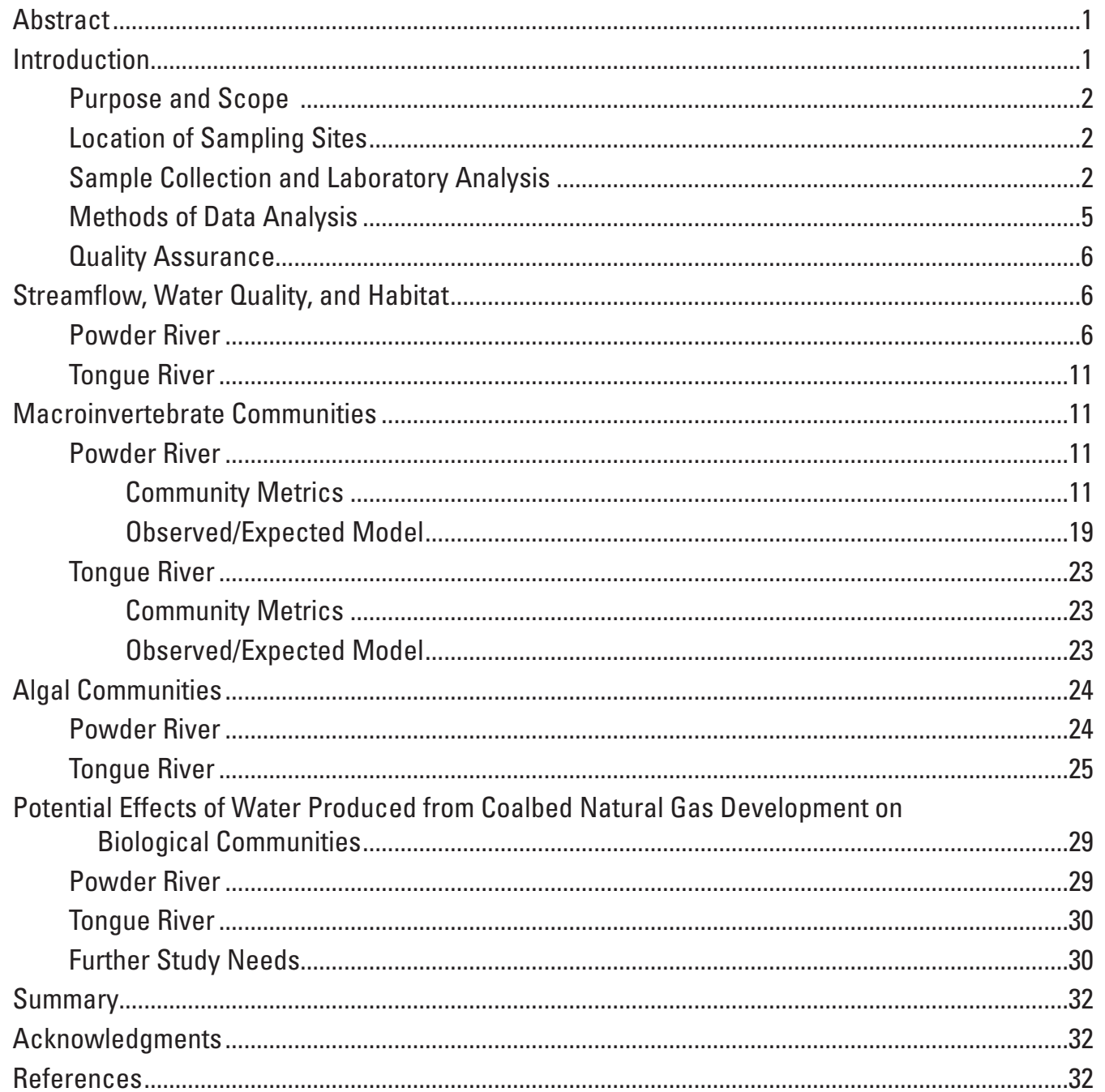

\section{Figures}

1. Map showing location of aquatic ecological sampling sites and selected streamgages on the Powder River and Tongue River, Wyoming and Montana, 2010

2. Hydrographs for the Powder River at Arvada, July 15-31, 2010, and the Tongue River at the Montana-Wyoming State Line, September 1-17, 2010

3. Graphs showing instantaneous streamflow, water-quality, and habitat measurements from ecological sampling sites on the Powder River, July 2010, and the Tongue River, September 2010, Wyoming and Montana 
4. Boxplots of selected macroinvertebrate community metrics from ecological sampling sites, Powder River and Tongue River, Wyoming and Montana, 2010

5. Boxplots of macroinvertebrate observed/expected model scores from ecological sampling sites, Powder River and Tongue River, Wyoming and Montana, 2010

6. Graphs showing algal community metrics for ecological sampling sites on the Powder River and Tongue River, Wyoming and Montana, 2010

7. Graphs showing comparison of mean macroinvertebrate metric scores from 2005-08 to mean scores from 2010, Powder River, Wyoming 31

\section{Tables}

1. Ecological sampling sites on the Powder River and Tongue River, Wyoming and Montana, 2010.

2. Environmental variables associated with biological samples, Powder River and Tongue River, Wyoming and Montana, 2010

3. Macroinvertebrate community metrics, Powder River and Tongue River, Wyoming and Montana, 2010

4. Analysis of variance for macroinvertebrate community metrics, Powder River and Tongue River, Wyoming and Montana, 2010

5. Observed/expected scores and analysis of variance among mean scores for macroinvertebrate communities, Powder River and Tongue River, Wyoming and Montana, 2010

6. Algal community metrics for the Powder River and Tongue River, Wyoming and Montana, 2010

\section{Conversion Factors and Datums}

\begin{tabular}{|c|c|c|}
\hline Multiply & By & To obtain \\
\hline foot $(\mathrm{ft})$ & 0.3048 & meter $(\mathrm{m})$ \\
\hline mile (mi) & 1.609 & kilometer $(\mathrm{km})$ \\
\hline centimeter & 0.3937 & inch (in.) \\
\hline cubic foot per second $\left(\mathrm{ft}^{3} / \mathrm{s}\right)$ & 0.3048 & cubic meter per second $\left(\mathrm{m}^{3} / \mathrm{s}\right)$ \\
\hline micrometer $(\mu \mathrm{m})$ & 0.00003937 & inch (in.) \\
\hline millimeter $(\mathrm{mm})$ & 0.03937 & inch (in.) \\
\hline
\end{tabular}

Temperature in degrees Celsius $\left({ }^{\circ} \mathrm{C}\right)$ may be converted to degrees Fahrenheit $\left({ }^{\circ} \mathrm{F}\right)$ as follows:

$$
{ }^{\circ} \mathrm{F}=\left(1.8 \mathrm{x}^{\circ} \mathrm{C}\right)+32
$$


Vertical coordinate information is referenced to the National Geodetic Vertical Datum of 1929 (NGVD 29).

Elevation, as used in this report, refers to distance above the vertical datum.

Horizontal coordinate information is referenced to the North American Datum of 1927 (NAD 27).

Specific conductance is given in microsiemens per centimeter at 25 degrees Celsius $(\mu \mathrm{S} / \mathrm{cm}$ at $\left.25^{\circ} \mathrm{C}\right)$.

Concentrations of chemical constituents in water are given in either milligrams per liter (mg/L) or micrograms per liter ( $\mu \mathrm{g} / \mathrm{L})$. Concentrations of algal constituents are given in milligrams per square meter $\left(\mathrm{mg} / \mathrm{m}^{2}\right)$, grams per square meters $\left(\mathrm{g} / \mathrm{m}^{2}\right)$, billion cells per square meter, or cubic centimeters per square meter $\left(\mathrm{cm}^{3} / \mathrm{m}^{2}\right)$.

The water year begins 0 ctober 1 and ends September 30, and is designated by the year in which it ends. For example, water year 2005 begins October 1, 2004, and ends September 30, 2005.

\title{
Abbreviations, Acronyms, Initialisms, and Symbols
}

\author{
$<\quad$ less than \\ $\leq \quad$ less than or equal to \\ $>\quad$ greater than \\ $\geq \quad$ greater than or equal to \\ ANOVA analysis of variance \\ ATG Aquatic Task Group \\ BC Bray-Curtis \\ BLM U.S. Department of the Interior Bureau of Land Management \\ CBNG coalbed natural gas \\ $D_{84} \quad$ diameter of the 84th percentile of particles \\ GPS global positioning system \\ IWG Interagency Working Group \\ MFWP Montana Fish, Wildlife, and Parks \\ MDEO Montana Department of Environmental Quality \\ NTRU nephelometric turbidity ratio units \\ $\mathrm{p} \quad$ probability level \\ O/E observed/expected \\ OC quality control \\ RPD Relative percent difference \\ USEPA U.S. Environmental Protection Agency \\ USGS U.S. Geological Survey \\ WDEO Wyoming Department of Environmental Quality \\ WGFD Wyoming Game and Fish Department
}





\title{
Assessment of Potential Effects of Water Produced from Coalbed Natural Gas Development on Macroinvertebrate and Algal Communities in the Powder River and Tongue River, Wyoming and Montana, 2010
}

\author{
By David A. Peterson', Eric G. Hargett ${ }^{2}$, and David L. Feldman ${ }^{3}$
}

\section{Abstract}

Ongoing development of coalbed natural gas in the Powder River structural basin in Wyoming and Montana led to formation of an interagency aquatic task group to address concerns about the effects of the resulting production water on biological communities in streams of the area. Ecological assessments, made from 2005-08 under the direction of the task group, indicated biological condition of the macroinvertebrate and algal communities in the middle reaches of the Powder was lower than in the upper or lower reaches. On the basis of the 2005-08 results, sampling of the macroinvertebrate and algae communities was conducted at 18 sites on the mainstem Powder River and 6 sites on the mainstem Tongue River in 2010. Sampling-site locations were selected on a paired approach, with sites located upstream and downstream of discharge points and tributaries associated with coalbed natural gas development. Differences in biological condition among site pairs were evaluated graphically and statistically using multiple lines of evidence that included macroinvertebrate and algal community metrics (such as taxa richness, relative abundance, functional feeding groups, and tolerance) and output from observed/expected $(\mathrm{O} / \mathrm{E})$ macroinvertebrate models from Wyoming and Montana.

Multiple lines of evidence indicated a decline in biological condition in the middle reaches of the Powder River, potentially indicating cumulative effects from coalbed natural gas discharges within one or more reaches between Flying $\mathrm{E}$ Creek and Wild Horse Creek in Wyoming. The maximum concentrations of alkalinity in the Powder River also occurred in the middle reaches. Biological condition in the upper and lower reaches of the Powder River was variable, with declines between some site pairs, such as upstream and downstream of

\footnotetext{
${ }^{1}$ U.S. Geological Survey.

${ }^{2}$ Wyoming Department of Environmental Quality.

${ }^{3}$ Montana Department of Environmental Quality.
}

Dry Fork and Willow Creek, and increases at others, such as upstream and downstream of Beaver Creek.

Biological condition at site pairs on the Tongue River showed an increase in one case, near the Wyoming-Montana border, and a decrease in another case, upstream of Tongue River Reservoir. Few significant differences were noted from upstream to downstream of Prairie Dog Creek, a major tributary to the Tongue River. Further study would be needed to confirm the observed patterns and choose areas to examine in greater detail.

\section{Introduction}

Development of energy and mineral resources in the Powder River structural basin in northeastern Wyoming and southeastern Montana (fig. 1) includes coalbed natural gas, conventional oil and gas, and coal mining. A common byproduct of coalbed natural gas $(\mathrm{CBNG})$ development is discharge of groundwater that commonly is saline or unsuitable for irrigation of crops and has unknown effects on the aquatic communities inhabiting streams that receive the water (Bureau of Land Management, 2009).

To address concerns about the potential effects of CBNG development on cultural and natural resources, the U.S. Department of the Interior Bureau of Land Management (BLM) formed an Interagency Working Group (IWG) of Federal, State, and tribal agencies. The charter of the IWG states that it "... was established as the forum for government agencies to address, discuss, and find solutions to issues of common concern to all parties involved in permitting and monitoring of CBNG development" (Powder River Natural Gas Interagency Working Group, 2004). The IWG charter also provides for establishment of working groups to address technical issues as envisioned by the April 2003 Record of Decision (Bureau of Land Management, 2003). One working group, the Aquatic Task Group (ATG), was tasked with assessing potential effects of $\mathrm{CBNG}$ produced water on 
aquatic ecological resources. Agencies involved in the ATG include the BLM, the Wyoming Department of Environmental Quality (WDEQ), Montana Department of Environmental Quality (MDEQ), the Wyoming Game and Fish Department (WGFD), the Montana Department of Fish, Wildlife, and Parks (MFWP), and the U.S. Environmental Protection Agency (USEPA).

The ATG developed a monitoring plan to meet two main objectives: (1) establish current ecological conditions for aquatic biota and their habitat, and (2) determine existing and potential effects of CBNG-produced water on aquatic life (Bureau of Land Management, 2009). The assessment of current ecological conditions as of 2005-08 was performed by the U.S. Geological Survey (USGS) under the direction of the ATG (Peterson and others, 2009; 2010). The determination of effects from CBNG-produced water is addressed in part by this study, as well as by studies of potential effects of CBNG water on fish communities in the study area (Davis, 2008; Skaar and others, 2006) and a literature review of the effects of CBNG activities on fish communities (Davis and others, 2009).

Results of the current-conditions study for 2005-08 indicated that an approximately 33-mile length of the Powder River, from Willow Creek downstream to below Crazy Woman Creek (named the middle reach), contained macroinvertebrate and algal communities distinct from those of the upper and lower reaches of the Powder River (Peterson and others, 2010). For example, macroinvertebrate taxa richness, relative abundance, functional feeding group, and tolerance metrics, which together are indicative of communitywide differences, indicated decreased biological condition in the middle reach of the Powder River relative to the upper and lower reaches (Peterson and others, 2010). In part because of those differences, the ATG adopted a focused paired-site study design in 2010 where sample site pairs were located above and below known discharges (either direct or via tributaries) of CBNG effluent to the Powder River in Wyoming and the Tongue River in Montana and Wyoming. The assumption of this paired-site study design is that any naturally occurring changes or non-CBNG anthropogenic activities would be similar between site pairs, so that any appreciable changes in macroinvertebrate and/or algal communities that occur within the site pair may be attributed to influences from CBNG effluent. In addition, sampling sites were located on the Tongue River upstream and downstream of Hanging Woman Creek related to potential effects of planned coal development in the Hanging Woman Creek drainage. Additional information about CBNG development and monitoring is available from the BLM at http://www.wy.blm.gov/prbgroup/; the Wyoming Department of Environmental Quality (WDEQ) at $h t t p: / / d e q$. state.wy.us/wqd/WYPDES_Permitting/WYPDES_cbm/cbm. asp; and the USGS at http://wy.water.usgs.gov/.

\section{Purpose and Scope}

The purpose of this report is to assess macroinvertebrate and algal communities upstream and downstream of CBNG discharges in the Powder River structural basin during 2010. Macroinvertebrate and algal samples were collected from 18 sites on the main stem of the Powder River in Wyoming and 6 sites on the main stem of the Tongue River in Wyoming and Montana. Related data collected in conjunction with the biological samples included streamflow discharge, water quality (major ions and field measurements), pebble counts, and microhabitat associated with biological sample collection points. Digital photographs and global positioning system (GPS) coordinates also were obtained at each site.

\section{Location of Sampling Sites}

Sampling sites generally were located in pairs upstream and downstream of direct discharges or tributaries contributing CBNG effluents to the Powder River and Tongue River (table 1; fig. 1). In some cases, the downstream site for one pair is also the upstream site for the next pair of sites. The sites on the Tongue River upstream and downstream of Hanging Woman Creek (sites TR5 and TR6) are an exception because their location is related to potential effects of planned coal development in the Hanging Woman Creek drainage.

\section{Sample Collection and Laboratory Analysis}

Ecological sampling in late July for the Powder River and mid-September for the Tongue River was timed to mimic seasonal sampling periods on those rivers during 2005-08 (Peterson and others, 2010). Macroinvertebrate samples were collected from multiple riffles (where available) at each site, using a Slack sampler (Moulton and others, 2002). Triplicate macroinvertebrate samples (labeled A, B, and C) were collected at each site as a measure of variability. Each macroinvertebrate sample was a composite from five areas, each defined by a square sampling frame measuring 50 centimeters (cm) by $50 \mathrm{~cm}\left(0.25 \mathrm{~m}^{2}\right)$, which sums to $1.25 \mathrm{~m}^{2}$ total area per sample. Triplicate samples were collected side-by-side among one or more riffles until five grabs were collected for all three samples (15 total). Each of the triplicate macroinvertebrate samples was composited and elutriated separately. Macroinvertebrate samples were preserved in ethanol and sent to the Buglab at Utah State University in Logan, Utah, for taxonomic identification. Chironomid taxonomy was subcontracted to Rhithron Associates, Inc. in Missoula, Mont.

Algal samples were collected by scraping rocks from riffles in the same general area as the macroinvertebrate samples (Moulton and others, 2002). The general procedure was to collect five undisturbed rocks near each of the five macroinvertebrate grabs, for a total of 25 rocks per algal sample. Algae 


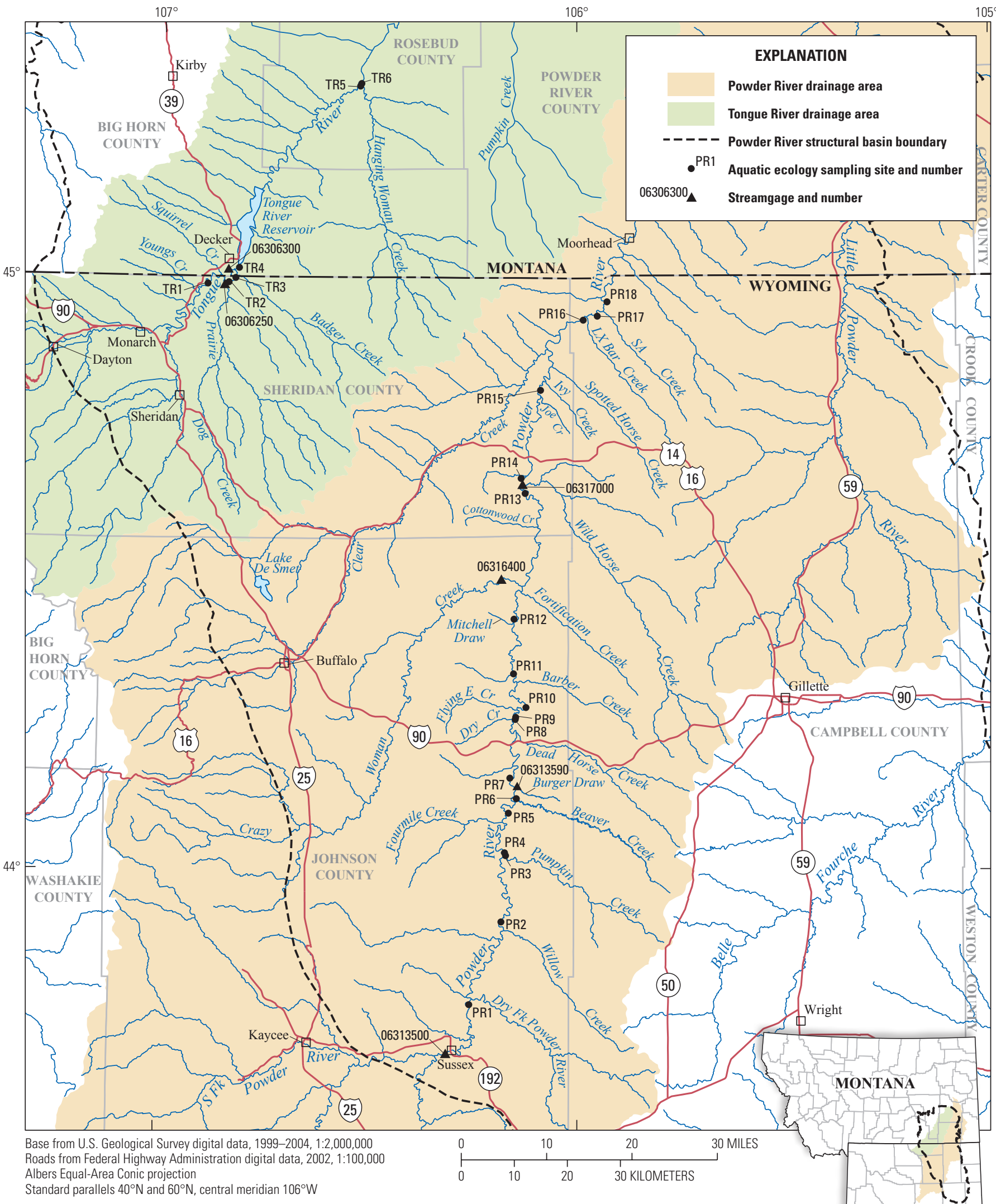

Figure 1. Location of aquatic ecological sampling sites and selected streamgages on the Powder River and WYOMING Tongue River, Wyoming and Montana, 2010. 


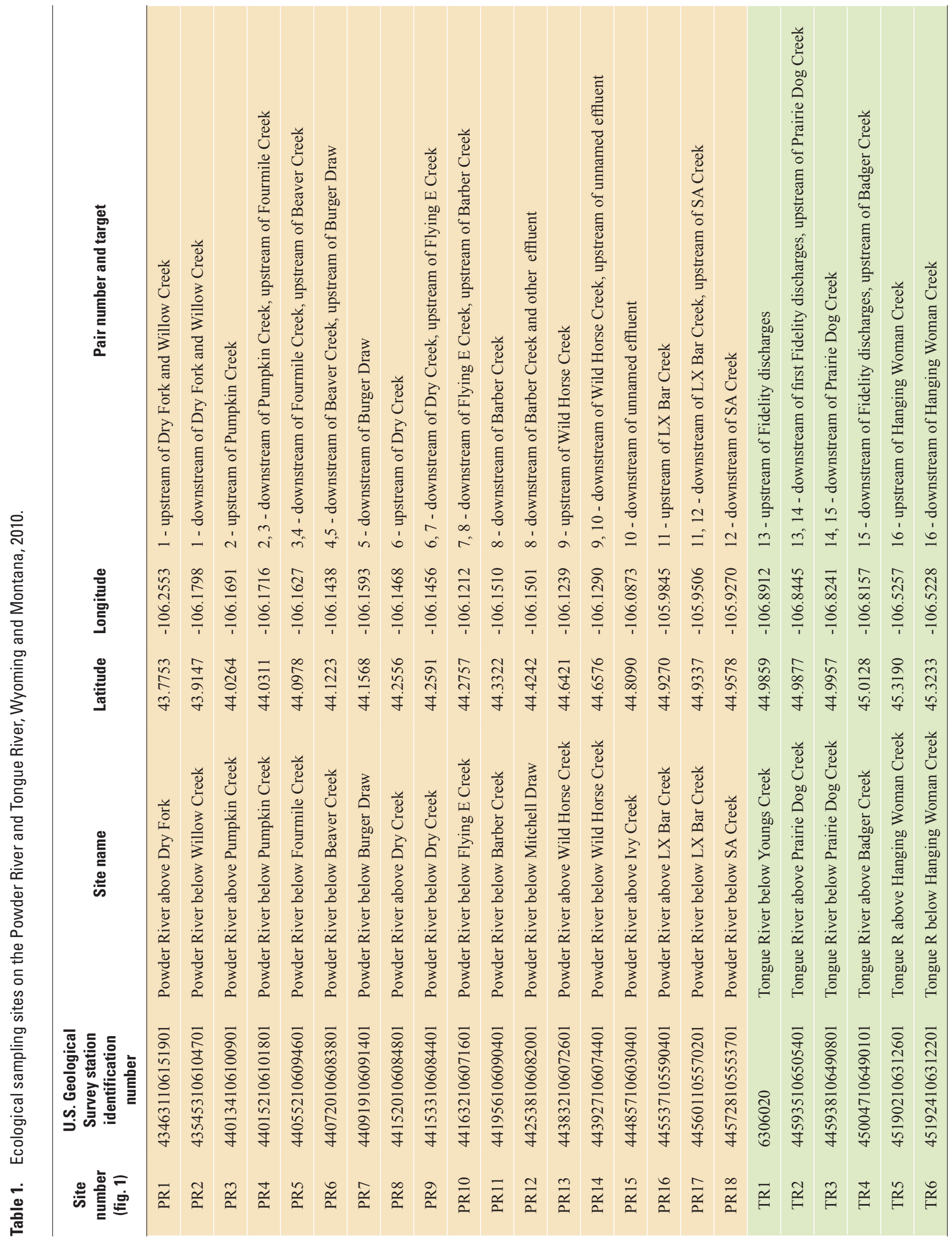


on each rock were scraped using a PVC-ring (about $18.8 \mathrm{~cm}^{2}$ area) to delimit a composite area of $471 \mathrm{~cm}^{2}$ total per sample. Algal samples were preserved in formalin and sent to Rhithron Associates, Inc., in Missoula, Mont., for taxonomic identification following standard WDEQ protocols.

Prior to ecological sampling, cross-sectional measurements of field parameters (specific conductance, $\mathrm{pH}$, dissolved oxygen, and water temperature) were recorded at each site to ensure that the river was well mixed. Field parameters were measured at regular intervals, typically every 5 feet, across the stream. If the field parameters indicated the stream was not well mixed, the crew moved downstream and repeated the cross-sectional measurement process. Depth- and widthintegrated water-quality samples were collected and composited in a churn at each site following standard USGS protocols (U.S. Geological Survey, variously dated) and sent to the USGS National Water-Quality Laboratory for analysis of major ions. Turbidity was measured onsite. Streamflow was measured at each site at the time of ecological sampling, following Rantz and others (1982).

A Wolman pebble count was conducted across riffles at each site, along a transect generally from bankfull to bankfull (Wolman, 1954). The exception to the bankfull cross section occurred at site PR15, where the riffle habitat was confined to a narrow edge along the left bank. The pebble count at site PR15 was conducted within the riffle habitat, parallel to the left bank. A minimum of 100 particles per site were measured for the pebble count. Microhabitat measures recorded with each of the macroinvertebrate and algal grabs were depth, velocity, riffle embeddedness, and substrate class (Moulton and others, 2002). The microhabitat substrate class was determined by visually estimating the dominant substrate at the grab point and assigning a numeric score of 3 for sand ( $>0.063-2$ millimeters $(\mathrm{mm})), 4$ for fine to medium gravel $(<2-16 \mathrm{~mm}), 5$ for coarse gravel $(>16-32 \mathrm{~mm})$, 6 for very coarse gravel $(<32-64 \mathrm{~mm}), 7$ for small cobble $(<64-128 \mathrm{~mm})$, and 8 for large cobble $(<128-256 \mathrm{~mm})$.

\section{Methods of Data Analysis}

Biological community metrics were calculated using procedures and attributes described by Cuffney (2003) for macroinvertebrates and by Porter (2008) for algae. Macroinvertebrate tolerance scores (Hilsenhoff, 1987; Cuffney, 2003) were assigned to one of three ranges: intolerant, greater than or equal to $(\geq) 0$ to less than or equal to $(\leq) 4$; moderately tolerant, greater than $(>) 4$ to less than $(<)$ 7; and tolerant, $\geq 7$ to $\leq 10$. The Shannon diversity index, nitrogen fixation, motility, and benthic-sestonic (substrate-attached and -unattached) metrics were computed for the entire algal community (Porter, 2008). Salinity, nitrogen uptake metabolism, saprobien system, and $\mathrm{pH}$ tolerance metrics were computed only for the diatom community (Van Dam and others, 1994). The relative abundance of halophilic diatoms, those preferring high salinity, was calculated from the sum of categories brackish-fresh and brackish species, and the relative abundance of nitrogen autotrophs was calculated from the sum of categories autotrophs low nitrogen and autotrophs high nitrogen, as described by Van Dam and others (1994).

Statistical comparisons of macroinvertebrate community metrics were performed in Spotfire S+ (TIBCO Software Inc., 2008 ) at a probability level (p) of 0.05 . Following procedures described by Helsel and Hirsch (2002), Kruskal-Wallis ranksum tests were used to look for significant differences in metric values within the Powder River group (sites PR1-PR18) and the Tongue River group (sites TR1-TR4). Rank-transformed data for groups with significant differences were subsequently tested for differences between sites using analysis of variance (ANOVA) and Tukey's test for multiple comparisons. Metrics from sites TR5-TR6 were tested using a Wilcoxon rank-sum test appropriate for a pair of sites instead of the group tests.

The Observed/Expected (O/E) models developed by the States of Wyoming (Hargett and others, 2005; 2007) and Montana (Montana Department of Environmental Quality, 2006) also were used to evaluate the macroinvertebrate data. Application of both O/E models by Peterson and others (2009) have shown them to be sensitive for detection of environmental change within the ATG study area. Similar to other multivariate predictive models such as RIVPACS (Clarke and others, 2003; Moss and others, 1987; Wright and others, 1993) and its derivatives, the Wyoming and Montana O/E models are statewide macroinvertebrate-based predictive models that provide an assessment of biological condition by comparing the macroinvertebrate taxa observed at a site of unknown biological condition to the indigenous macroinvertebrate taxa expected to occur (probability of occurrence $>50$ percent) in the absence of human stress. Predictor variables, such as site latitude and longitude, substrate type, precipitation, air temperature, watershed area, elevation and geology were used to construct the models. The expected macroinvertebrate taxa were derived from an appropriate set of reference sites that were minimally or least affected by anthropogenic stress. The deviation of the observed from the expected taxa, known as the $\mathrm{O} / \mathrm{E}$ score, is a measure of the compositional similarity expressed in units of taxa richness and, thus, is a communitylevel measure of biological condition. Such O/E scores near 1 imply high biological condition similar to expected conditions, whereas $\mathrm{O} / \mathrm{E}$ scores less than 1 imply some degree of biological degradation as a result of the absence of expected taxa. The reference expectations for the Wyoming and Montana invertebrate $\mathrm{O} / \mathrm{E}$ models were each developed from a network of reference sites within the state of origin. Thus the geographic application of each model is generally restricted to within the state for which it was developed. For these reasons, the Wyoming $\mathrm{O} / \mathrm{E}$ model was applied only to macroinvertebrate data from Powder River sites, whereas Tongue River sites were evaluated with the Montana O/E model.

The Bray $\square$ Curtis (BC) index was calculated from outputs of the invertebrate $\mathrm{O} / \mathrm{E}$ models to evaluate potential taxa replacement issues that might not be captured by the $\mathrm{O} / \mathrm{E}$ 
model (Van Sickle, 2008). The BC index allows comparison of an observed sample to an expected population based upon the same probability of capture scores used in the $\mathrm{O} / \mathrm{E}$ model. The $\mathrm{BC}$ index is designed to provide a more accurate evaluation of a macroinvertebrate sample because it will not allow the influence of rare or additional taxa to affect the final result. The $\mathrm{O} / \mathrm{E}$ model can be biased when rare or unexpected taxa replace common ones. Van Sickle (2008) demonstrated how this could result in a good final $\mathrm{O} / \mathrm{E}$ score when the opposite may be true. The $\mathrm{BC}$ index ranges between 0 and 1 , where 0 is the most similar to the expected reference population, and 1 is the score for the least similar to reference.

\section{Quality Assurance}

Quality assurance for analyses of major ions included collection and analysis of quality-control (QC) samples from two sites (10 percent of samples). Concentrations of all major ions in a blank sample collected at site PR10 were less than the laboratory reporting limits with the exception of chloride that was three orders of magnitude less than the concentration of chloride in the corresponding environmental sample. The other QC sample for major ions was a split collected at site PR1. The relative percentage difference (RPD) in constituent concentrations between the environmental (sample 1) and the split (sample 2) sample was calculated using the formula:

$$
\begin{gathered}
\mathrm{RPD}=\text { absolute value }((\text { sample } 1-\text { sample } 2) /[(\text { sample } 1+ \\
\text { sample 2)/2]) } \times 100
\end{gathered}
$$

The RPD between the environmental and split samples was less than 5 percent difference for all of the major ions.

Quality assurance for pebble counts consisted of triplicate pebble counts at two sites. The $\mathrm{D}_{84}$, or diameter of the 84th percentile of particles, is presented as an indicator for comparison of the triplicates. The RPD between the triplicates collected at PR5 was 30, 14, and 44 percent difference, respectively, in the $\mathrm{D}_{84}$ values. The RPD between the triplicates collected at site TR2 was $0,3.6$, and 3.6 percent difference in the $\mathrm{D}_{84}$ values. In order to provide a better estimate for data analysis in later sections of this report, the triplicate pebble counts were composited at each site, thereby providing a pebble count of more than 300 particles for sites PR5 and TR2.

Taxonomic QC samples for invertebrates were provided by the triplicate samples collected at each site. The variation among the triplicate samples was analyzed through various techniques, such as ANOVA, described in the sections, "Methods of Data Analysis" and "Macroinvertebrate Communities."

Taxonomic QC samples for algae were collected at site PR12 (environmental, split, and replicate samples) and at site PR14 (environmental and replicate samples). The algae QC samples were compared to the environmental samples using BC similarity coefficients (Bray and Curtis, 1957). The similarity coefficients of the algae QC samples ranged from 68 to 73 percent, on a scale from 0 (no similarity) to 100 percent (complete similarity).

\section{Streamflow, Water Quality, and Habitat}

Streamflow and water-quality data are available from the USGS websites: http://waterdata.usgs.gov/wy/nwis/nwis for Wyoming and http://waterdata.usgs.gov/mt/nwis/nwis for Montana.

\section{Powder River}

Streamflow in the Powder River generally was stable at the time of sampling. The Powder River was in a normal seasonal recession in late July although streamflow was higher than long-term median values for the Powder River at Arvada (fig. 2). Localized thunderstorms in the Powder River drainage during the evening of July 21 produced a small increase (less than 5 percent) in streamflow at Arvada (streamgage 06317000, between sites PR13 and PR14) on July 22 (fig. 2), but data from other streamgages on the Powder River (at Sussex, 06313500, and above Burger Draw, 06313590) did not show a similar increase.

Streamflow in the Powder River exhibited a general increase in the downstream direction from 77 cubic feet per second $\left(\mathrm{ft}^{3} / \mathrm{s}\right.$ ) at site PR1 to $146 \mathrm{ft}^{3} / \mathrm{s}$ at site PR18 (table 2). An abrupt increase in streamflow of $103 \mathrm{ft}^{3} / \mathrm{s}$ was noted between site PR12 (below Mitchell Draw) and site PR13 (above Wild Horse Creek) (fig. 3). Most of the increase in flow between sites PR12 and PR13 could be attributed to inflow from Crazy Woman Creek (streamgage 06316400), however, about $30 \mathrm{ft}^{3} / \mathrm{s}$ was not accounted for, considering zero contributions from precipitation events either directly or via ephemeral tributaries such as Cottonwood Creek and Fortification Creek. Direct discharge of CBNG effluent to the Powder River is unlikely to have contributed the remaining $30 \mathrm{ft}^{3} / \mathrm{s}$ (Jeremy Zumberge, Wyoming Department of Environmental Quality, personal commun., 2010). Other potential reasons for the increase of $30 \mathrm{ft}^{3} / \mathrm{s}$ in this reach include alluvial recharge, measurement error, or additional flow in Crazy Woman Creek between streamgage 06316400 and the confluence with the Powder River (2.3 air miles). The increase in streamflow between sites PR12 and PR13 in 2010 was in contrast to previous work (Ringen and Daddow, 1990, and Peterson and others, 2010) that documented periods of no flow in the same area. The overall decrease in streamflow downstream of site PR14 (fig. 3) is presumably due to alluvial infiltration, given that the reach of the Powder River from Arvada to Moorhead has been described as a losing reach (Ringen and Daddow, 1990).

Specific conductance, alkalinity, and sodium concentrations varied among Powder River sites. Values for those constituents were highest at sites PR10-PR12 (fig. 3), from below Flying E Creek to below Mitchell Draw. Contributions 

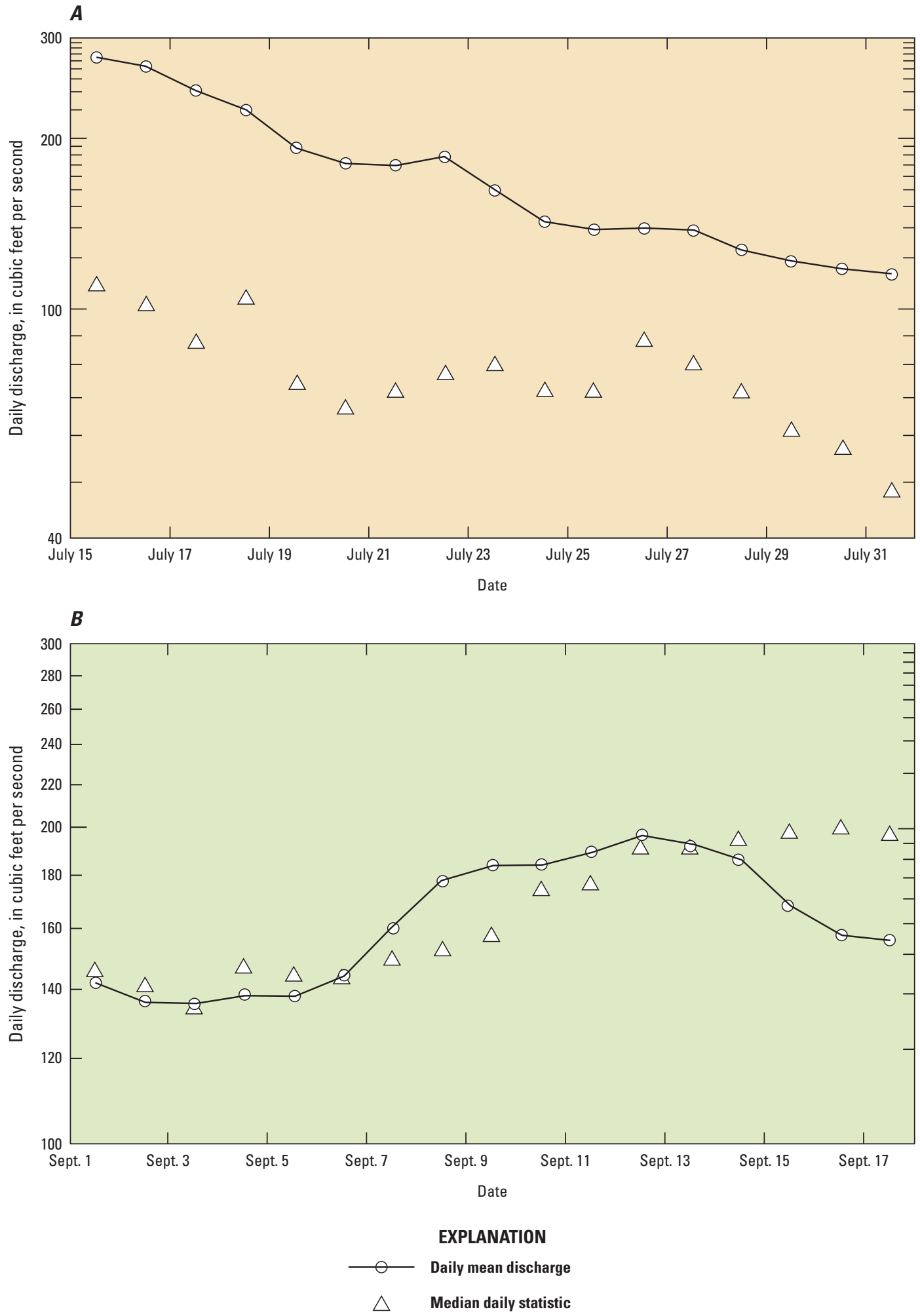

Figure 2. Hydrographs for $A$, the Powder River at Arvada (streamgage 06317000), July 15-31, 2010, and $B$, the Tongue River at the Montana-Wyoming State Line (streamgage 06306300), September 1-17, 2010. 
of produced water from CBNG activities via Flying E Creek, Barber Creek, and other tributaries is a potential source because elevated concentrations of these constituents and related properties have been reported in CBNG effluent (Rice and others, 2000). Specific conductance, alkalinity, and sodium concentrations dropped considerably from site PR 12 to site PR13, coincident with the previously described increase in streamflow coupled with dilution by lower ionic-strength water from Crazy Woman Creek (about 1,200 microsiemens per centimeter $(\mu \mathrm{S} / \mathrm{cm}))$. Specific conductance, alkalinity, and sodium concentrations increased from site PR14, below Wild Horse Creek, to site PR15, above Ivy Creek. For example, specific conductance increased from $1,880 \mu \mathrm{S} / \mathrm{cm}$ at site PR14 to $2,130 \mu \mathrm{S} / \mathrm{cm}$ at site PR15, whereas streamflow decreased, consistent with the losing reach described earlier. Water produced from CBNG activities is a potential source of the elevated constituents at site PR15 but is too small a volume of water to result in increased streamflow. Inflow of lower specific-conductance water from Clear Creek likely was responsible for the decrease in specific conductance, alkalinity,

Table 2. Environmental variables associated with biological samples, Powder River and Tongue River, Wyoming and Montana, 2010.

$\left[\mathrm{ft}^{3} / \mathrm{s}\right.$, cubic feet per second; std, standard; mg/L, milligrams per liter; $\mu \mathrm{S} / \mathrm{cm}$, microsiemens per centimeter; deg C, degrees Celsius; NTRU, nephelometric turbidity ratio units; $\mathrm{CaCO}_{3}$, calcium carbonate; $\%$, percent; $\mathrm{mm}$, millimeter; $\mathrm{D}_{50}$, diameter of the 50 th percentile of particles; $\mathrm{D}_{84}$, diameter of the 84 th percentile of particles; Microhabitat values represent average of five measurements; ft/s, feet per second; <, less than; NA, not available]

\begin{tabular}{|c|c|c|c|c|c|c|c|c|c|c|c|c|}
\hline \multirow[b]{2}{*}{$\begin{array}{c}\text { Site } \\
\text { number }\end{array}$} & \multirow[b]{2}{*}{$\begin{array}{c}\text { Sample } \\
\text { date }\end{array}$} & \multirow[b]{2}{*}{$\begin{array}{c}\text { Instaneous } \\
\text { discharge } \\
\left(\mathrm{ft}^{3} / \mathrm{s}\right)\end{array}$} & \multicolumn{5}{|c|}{ Field measurements } & \multicolumn{5}{|c|}{ Major ions } \\
\hline & & & $\begin{array}{c}\text { Dissolved } \\
\text { oxygen } \\
\text { (mg/L) }\end{array}$ & $\begin{array}{c}\text { pH } \\
\text { (std } \\
\text { units) }\end{array}$ & $\begin{array}{c}\text { Specific } \\
\text { conduc- } \\
\text { tance } \\
(\mu \mathrm{S} / \mathrm{cm})\end{array}$ & $\begin{array}{c}\text { Water } \\
\text { tempera- } \\
\text { ture } \\
(\operatorname{deg} C)\end{array}$ & $\begin{array}{c}\text { Turbidity } \\
\text { (NTRU) }\end{array}$ & $\begin{array}{c}\text { Calcium } \\
\text { (mg/L) }\end{array}$ & $\begin{array}{l}\text { Mag- } \\
\text { nesium } \\
\text { (mg/L) }\end{array}$ & $\begin{array}{l}\text { Potassium } \\
\text { (mg/L) }\end{array}$ & $\begin{array}{l}\text { Sodium } \\
\text { adsorption } \\
\text { ratio }\end{array}$ & $\begin{array}{c}\text { Sodium } \\
\text { (mg/L) }\end{array}$ \\
\hline PR1 & $7 / 21 / 2010$ & 77 & 8.2 & 8.3 & 2,270 & 21.3 & 12 & 149 & 59.1 & 9.23 & 4.64 & 265 \\
\hline PR2 & $7 / 21 / 2010$ & 66 & 7.5 & 8.3 & 2,220 & 27.2 & 42 & 140 & 57.4 & 8.93 & 4.64 & 258 \\
\hline PR3 & $7 / 20 / 2010$ & 86 & 8.7 & 8.2 & 2,150 & 19.9 & 55 & 137 & 58.5 & 8.08 & 4.57 & 253 \\
\hline PR4 & $7 / 20 / 2010$ & 90 & 7.4 & 8.2 & 2,200 & 28.4 & 54 & 136 & 58.7 & 8.42 & 4.60 & 255 \\
\hline PR5 & $7 / 21 / 2010$ & 91 & 7.7 & 8.2 & 2,210 & 23.7 & 46 & 138 & 60.5 & 8.80 & 4.76 & 266 \\
\hline PR6 & $7 / 21 / 2010$ & 89 & 7.1 & 8.3 & 2,180 & 27.4 & 40 & 128 & 57.2 & 8.84 & 4.99 & 271 \\
\hline PR7 & $7 / 19 / 2010$ & 109 & 7.2 & 8.2 & 2,080 & 28.8 & 63 & 121 & 54.6 & 8.51 & 4.83 & 255 \\
\hline PR8 & $7 / 20 / 2010$ & 105 & 7.0 & 8.3 & 2,140 & 27.8 & 80 & 123 & 55.5 & 8.63 & 5.09 & 270 \\
\hline PR9 & $7 / 20 / 2010$ & 105 & 8.1 & 8.3 & 2,110 & 19.9 & 71 & 122 & 56.1 & 8.41 & 5.01 & 267 \\
\hline PR10 & $7 / 22 / 2010$ & 104 & 8.2 & 8.3 & 2,310 & 23.8 & 60 & 117 & 54.8 & 10.4 & 6.25 & 327 \\
\hline PR11 & $7 / 23 / 2010$ & 103 & 8.3 & 8.2 & 2,340 & 20.8 & 45 & 104 & 56.0 & 11.6 & 6.78 & 345 \\
\hline PR12 & $7 / 26 / 2010$ & 83 & 9.9 & 8.1 & 2,490 & 30.3 & NA & 79.9 & 54.0 & 12.8 & 8.31 & 392 \\
\hline PR13 & $7 / 22 / 2010$ & 186 & 6.3 & 8.4 & 1,930 & 21.2 & 4,030 & 115 & 55.5 & 8.22 & 4.52 & 236 \\
\hline PR14 & $7 / 22 / 2010$ & 206 & 6.0 & 8.3 & 1,880 & 27.0 & 1,440 & 111 & 53.6 & 8.37 & 4.42 & 226 \\
\hline PR15 & $7 / 27 / 2010$ & 117 & 7.4 & 8.3 & 2,130 & 22.2 & 100 & 94.6 & 53.6 & 9.32 & 6.24 & 307 \\
\hline PR16 & $7 / 27 / 2010$ & 154 & 7.6 & 8.5 & 1,880 & 24.5 & 71 & 102 & 54.5 & 8.50 & 4.86 & 244 \\
\hline PR17 & $7 / 28 / 2010$ & 143 & 7.6 & 8.5 & 1,890 & 21.5 & 45 & 98.0 & 53.5 & 8.38 & 5.05 & 250 \\
\hline PR18 & $7 / 28 / 2010$ & 146 & 7.9 & 8.5 & 1,950 & 26.7 & 76 & 101 & 56.3 & 8.75 & 5.16 & 261 \\
\hline TR1 & $9 / 13 / 2010$ & 135 & 11.2 & 8.4 & 527 & 18.2 & 14 & 42.5 & 23.4 & 2.67 & .82 & 26.9 \\
\hline TR2 & $9 / 14 / 2010$ & 176 & 9.1 & 8.4 & 534 & 16.0 & 14 & 51.0 & 30.7 & 2.20 & .54 & 19.6 \\
\hline TR3 & $9 / 14 / 2010$ & 177 & 12.3 & 8.6 & 592 & 18.4 & 13 & 57.6 & 35.1 & 2.71 & .65 & 25.4 \\
\hline TR4 & $9 / 16 / 2010$ & 119 & 5.9 & 8.3 & 698 & 14.9 & 9.2 & 60.4 & 36.2 & 2.94 & .99 & 39.3 \\
\hline TR5 & $9 / 15 / 2010$ & 283 & 8.4 & 8.5 & 498 & 18.6 & 8.8 & 50.8 & 29.6 & 2.13 & .50 & 18.1 \\
\hline TR6 & $9 / 15 / 2010$ & 283 & 7.0 & 8.5 & 488 & 17.6 & 7.2 & 43.6 & 24.0 & 2.60 & .82 & 27.3 \\
\hline
\end{tabular}

${ }^{1}$ Substrate class from Moulton and others (2002). 
and sodium downstream of site PR15. Concentrations of other major ions in the Powder River, such as sulfate (table 2), did not vary as much as alkalinity and sodium.

Substrate measurements showed variation in the Powder River. Substrate size was highly variable among sites in the Powder River, as indicated by pebble count $\mathrm{D}_{84}$ ranging from $4.5 \mathrm{~mm}$ at site PR9 to $106 \mathrm{~mm}$ at site PR17 (fig. 3). Microhabitat substrate class scores were also lowest at site PR9 but were highest at site PR10 (fig. 3). Microhabitat embeddedness also showed substantial variability between sites (table 2).

Table 2. Environmental variables associated with biological samples, Powder River and Tongue River, Wyoming and Montana, 2010.— Continued

[ft $/ \mathrm{s}$, cubic feet per second; std, standard; mg/L, milligrams per liter; $\mu \mathrm{S} / \mathrm{cm}$, microsiemens per centimeter; deg C, degrees Celsius; NTRU, nephelometric turbidity ratio units; $\mathrm{CaCO}_{3}$, calcium carbonate; $\%$, percent; $\mathrm{mm}$, millimeter; $\mathrm{D}_{50}$, diameter of the 50 th percentile of particles; $\mathrm{D}_{84}$, diameter of the 84 th percentile of particles; Microhabitat values represent average of five measurements; $\mathrm{ft} / \mathrm{s}$, feet per second; <, less than; NA, not available]

\begin{tabular}{|c|c|c|c|c|c|c|c|c|c|c|c|c|}
\hline \multicolumn{6}{|c|}{ Major ions } & \multicolumn{3}{|c|}{ Pebble count } & \multicolumn{4}{|c|}{ Invertebrate and algae microhabitat } \\
\hline $\begin{array}{c}\text { Alkalinity } \\
\text { (mg/L as } \\
\mathrm{CaCO}_{3} \text { ) }\end{array}$ & $\begin{array}{l}\text { Chloride } \\
\text { (mg/L) }\end{array}$ & $\begin{array}{c}\text { Fluoride } \\
\text { (mg/L) }\end{array}$ & $\begin{array}{l}\text { Silica } \\
\text { (mg/L) }\end{array}$ & $\begin{array}{l}\text { Sulfate } \\
\text { (mg/L) }\end{array}$ & $\begin{array}{c}\text { Dissolved } \\
\text { solids, sum } \\
\text { (mg/L) }\end{array}$ & $\begin{array}{l}\text { Less than } \\
2 \mathrm{~mm} \\
(\%)\end{array}$ & $\begin{array}{c}\mathrm{D}_{50} \\
(\mathrm{~mm})\end{array}$ & $\begin{array}{c}\mathrm{D}_{84} \\
(\mathrm{~mm})\end{array}$ & $\begin{array}{c}\text { Depth } \\
\text { (ft) }\end{array}$ & $\begin{array}{c}\text { Embedded- } \\
\text { ness } \\
(\%)\end{array}$ & $\begin{array}{c}\text { Velocity } \\
\text { (ft/s) }\end{array}$ & $\begin{array}{c}\text { Substrate } \\
\text { class }^{1}\end{array}$ \\
\hline 208 & 209 & 0.72 & 9.80 & 731 & 1,560 & 56.8 & $<2$ & 28 & 0.60 & 52 & 1.66 & 5.8 \\
\hline 183 & 193 & .66 & 9.96 & 722 & 1,500 & 75.5 & $<2$ & 35 & .48 & 30 & 1.07 & 6.0 \\
\hline 174 & 187 & .61 & 9.84 & 735 & 1,490 & 23.6 & 16.5 & 54 & .71 & 34 & 1.79 & 6.1 \\
\hline 162 & 187 & .59 & 9.92 & 739 & 1,490 & 37 & 22.6 & 56 & .50 & 12 & 1.84 & 5.2 \\
\hline 168 & 190 & .61 & 9.95 & 755 & 1,530 & 23.1 & 39 & 89 & 1.13 & 56 & 2.09 & 7.1 \\
\hline 190 & 181 & .66 & 9.81 & 720 & 1,490 & 15.1 & 44 & 88 & .69 & 52 & 2.08 & 6.3 \\
\hline 190 & 158 & .62 & 9.58 & 677 & 1,400 & 15.2 & 38 & 95 & .66 & 10 & 2.03 & 5.0 \\
\hline 204 & 164 & .64 & 8.91 & 702 & 1,450 & 20.2 & 13.5 & 30 & .45 & 40 & 1.43 & 5.0 \\
\hline 213 & 162 & .63 & 8.69 & 699 & 1,450 & 80.3 & $<2$ & 4.5 & .25 & 40 & .93 & 3.1 \\
\hline 288 & 172 & .70 & 9.02 & 688 & 1,550 & 13.8 & 18 & 91 & .41 & 43 & 1.84 & 7.6 \\
\hline 286 & 172 & .68 & 8.30 & 666 & 1,540 & 23.3 & 18 & 50 & .62 & 40 & 1.78 & 6.3 \\
\hline 305 & 175 & .74 & 7.26 & 683 & 1,590 & 7.7 & 20.5 & 65 & .56 & 50 & 1.96 & 7.2 \\
\hline 228 & 106 & .53 & 7.66 & 660 & 1,320 & 36.7 & 5.2 & 25 & .88 & 56 & 1.65 & 6.2 \\
\hline 226 & 100 & .52 & 7.94 & 641 & 1,280 & 25 & 20 & 97 & .80 & 30 & 2.91 & 6.2 \\
\hline 256 & 133 & .59 & 8.01 & 699 & 1,460 & 9.4 & 40 & 62 & .46 & 42 & .89 & 4.0 \\
\hline 230 & 99.4 & .51 & 6.55 & 620 & 1,270 & 2.7 & 40 & 62 & .53 & 37.5 & 2.45 & 4.6 \\
\hline 242 & 102 & .52 & 6.51 & 624 & 1,290 & 0 & 59 & 106 & .58 & 26 & 2.58 & 5.7 \\
\hline 244 & 98.9 & .52 & 6.51 & 642 & 1,320 & 2.9 & 38 & 73 & .53 & 36 & 2.20 & 4.4 \\
\hline 167 & 2.90 & .26 & 3.36 & 95.2 & 297 & 1.7 & 32 & 49 & .66 & 14 & 1.63 & 5.4 \\
\hline 211 & 3.32 & .26 & 3.32 & 80.3 & 317 & 4.2 & 37 & 55 & .64 & 10 & 1.82 & 6.3 \\
\hline 213 & 3.63 & .25 & 4.51 & 128 & 385 & 12.8 & 28 & 48 & .58 & 34 & 1.89 & 6.0 \\
\hline 239 & 4.50 & .35 & 3.09 & 147 & 437 & 10.7 & 20 & 32 & .61 & 34 & 1.15 & 5.9 \\
\hline 209 & 3.75 & .25 & 3.81 & 77.9 & 312 & 1 & 43 & 88 & .79 & 26 & 1.40 & 6.2 \\
\hline 166 & 2.92 & .24 & 3.45 & 93.7 & 297 & 0 & 42 & 63 & .81 & 16 & 1.80 & 5.4 \\
\hline
\end{tabular}




$$
\text { 交 }
$$
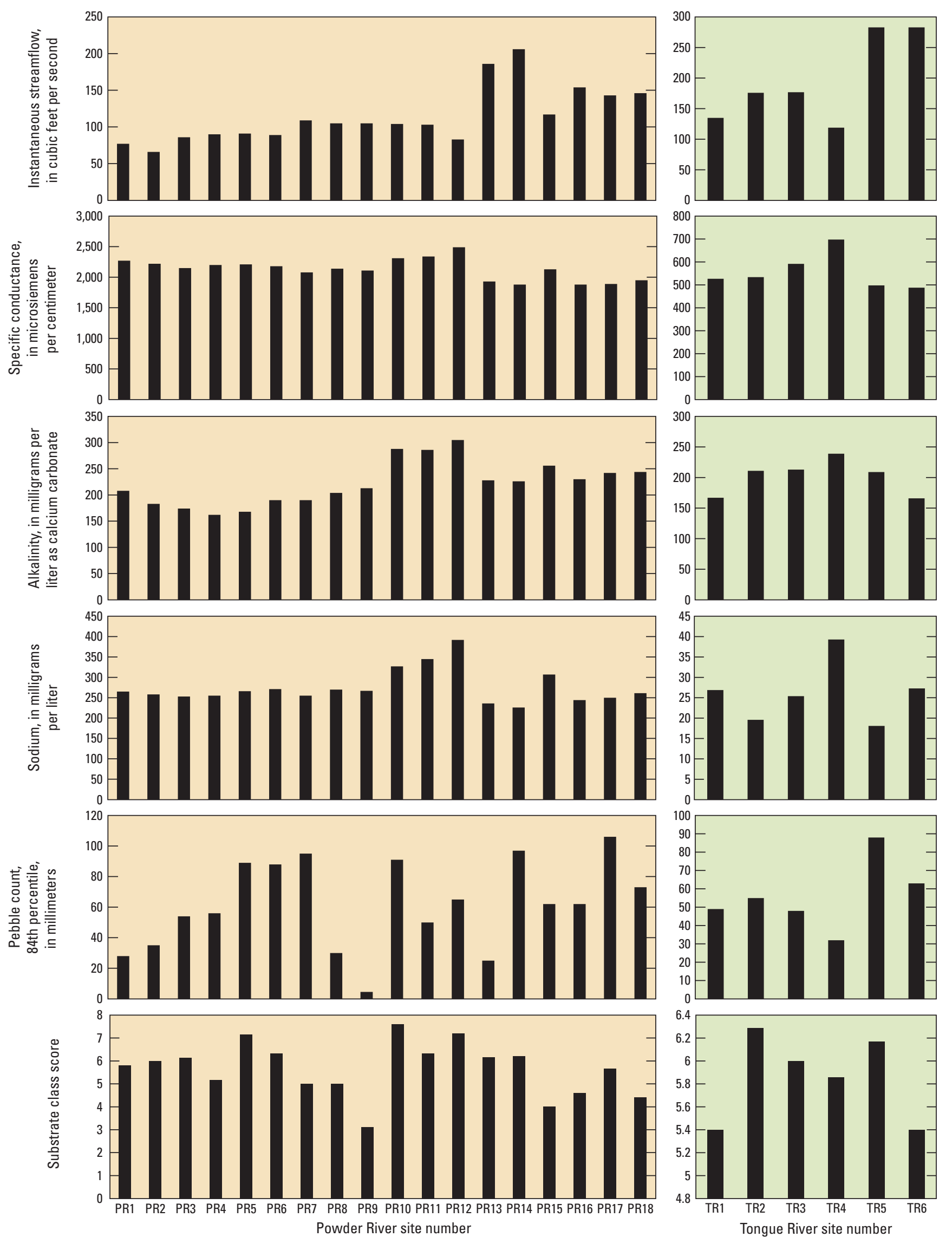

Figure 3. Instantaneous streamflow, water-quality, and habitat measurements from ecological sampling sites on the Powder River, July 2010, and the Tongue River, September 2010, Wyoming and Montana. 


\section{Tongue River}

The Tongue River was near the long-term median streamflow at the time of ecological sampling, as indicated by data from streamgage 06306300 at the state line (fig. 2). Streamflow increased with downstream distance, from $135 \mathrm{ft}^{3} / \mathrm{s}$ at site TR1 to $177 \mathrm{ft}^{3} / \mathrm{s}$ at site TR3, followed by a decrease to $119 \mathrm{ft}^{3} / \mathrm{s}$ at site TR4 (fig. 3, table 2). Inflows from tributaries such as Prairie Dog Creek, irrigation return flows and diversions, and CBNG-produced water contributed to the increase between sites TR1 and TR3. Diversions for irrigation might have caused the decrease in flow from TR3 to TR4. Streamflow at sites TR5 and TR6, downstream of Tongue River Reservoir, was $283 \mathrm{ft}^{3} / \mathrm{s}$.

Specific conductance upstream from Tongue River Reservoir increased from $527 \mu \mathrm{S} / \mathrm{cm}$ at site TR1 to $698 \mu \mathrm{S} / \mathrm{cm}$ at site TR4 (fig. 3). Alkalinity concentrations followed the same pattern, increasing from $167 \mathrm{mg} / \mathrm{L}$ at site TR 1 to $239 \mathrm{mg} / \mathrm{L}$ at site TR4 (fig. 3). Potential influences to water quality of the Tongue River between sites TR1 and TR4 include CBNG-produced water, tributary inflow, and irrigation return flows and diversions. Specific conductance of Prairie Dog Creek (streamgage 06306250) on the date of sampling was $984 \mu \mathrm{S} / \mathrm{cm}$ and considerably higher than at sites TR2 and TR3. Specific conductance at sites TR5 and TR6 was near $500 \mu \mathrm{S} / \mathrm{cm}$ and lower relative to sites TR1-TR4, likely due to the effects of Tongue River Reservoir. Specific conductance and sodium concentrations in the Tongue River were much lower than those in the Powder River, though alkalinity concentrations were similar (fig. 3).

Other variations included pebble count and substrate class scores. The pebble count $\mathrm{D}_{84}$ ranged from 32 to $55 \mathrm{~mm}$ at sites TR1-TR4, and from 63 to $88 \mathrm{~mm}$ at sites TR5-TR6 (fig. 3). Microhabitat substrate class scores indicated a different pattern, with minimum scores at sites TR1 and TR6, and maximum scores at sites TR2 and TR5.

\section{Macroinvertebrate Communities}

Macroinvertebrate communities of the Powder River are discussed separately from those of the Tongue River because of differences noted during earlier studies (Peterson and others, 2010) and confirmed from the 2010 samples. For example, communities of the Powder River generally contained a higher relative abundance of Diptera and lower relative abundance of Ephemeroptera and Trichoptera than communities of the Tongue River (table 3). Macroinvertebrate taxonomic data

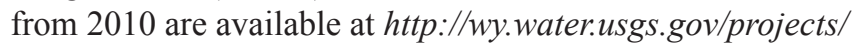
$\mathrm{atg} / \mathrm{htms} /$ data.htm (accessed October 6, 2011).

\section{Powder River}

\section{Community Metrics}

Kruskal-Wallis tests indicated significant $(\mathrm{p}<0.05)$ differences within the Powder River group for metrics including taxa richness, relative abundance, functional feeding group, and water-quality tolerance. Additional analysis using ANOVA and Tukey's multiple comparison test (table 4) indicated significant differences in metric values between some of the site pairs upstream and downstream of CBNG effluents and tributaries (table 1) as well as between other sites. Differences in metric values indicated a decline in biological condition between the upstream and downstream sites in some cases, and an increase in other cases. The Powder River was divided into three zones for the purposes of discussion. The upper reaches include sites PR1-PR9, the middle reaches include sites PR9-PR14, and the lower reaches include sites PR14-PR18.

Within the upper reaches of the Powder River, significant differences in metric values were noted at site pairs bracketing Dry Fork and Willow Creek (sites PR1-PR2), Beaver Creek (sites PR5-PR6), and Dry Creek (sites PR8-PR9). Significant differences in relative abundance of Ephemeroptera (increases at sites PR1-PR2 and PR8-PR9; table 4 and fig. 4), Trichoptera (increase at sites PR5-PR6; table 4), Diptera (decrease at sites PR5-PR6), and dominant taxon (decrease at all three site pairs) are consistent with an increase in biological condition using predicted responses to biological perturbation from Barbour and others (1999). The dominant taxon at most of the sites on the Powder River was the blackfly Simulium. For example, at sites PR5 and PR6, the decrease in dominant taxon was from an average of 90 percent Simulium spp. at PR5, to 62 percent at site PR6. At sites PR8 to PR9, the decrease in dominant taxon corresponded to a taxonomic shift as well, from an average of 59 percent Simulium spp. at site PR8, to 30 percent Saetheria (Chironomidae) at site PR9. The relative abundance of filterer-collectors decreased within each of the three site pairs (fig. 4). Barbour and others (1999) noted that functional feeding group response to perturbation is variable, but generalists such as filterer-collectors utilize a broader range of food materials than specialists, and thereby are more tolerant to perturbation. The observed decreases in filterer-collectors therefore are considered an increase in biological condition, particularly in combination with the increase in scrapers (a feeding specialist) at PR1 to PR2 and gatherer-collectors at PR8 to PR9 (table 3), and differences in relative abundance of Ephemeroptera, Trichoptera, Diptera, and dominant taxon as noted above.

Some of the site pairs in the upper reaches of the Powder River had no significant differences in metric values, including 


\section{Assessment of Coalbed Natural Gas Development in Powder and Tongue Rivers, Wyoming and Montana, 2010}

Pumpkin Creek (sites PR3-PR4), Fourmile Creek (sites PR4PR5), and Burger Draw (sites PR6-PR7). Although sites PR2 to PR3 were not specifically designed as a site pair (table 1), a notable decline in biological condition from sites PR2 to PR3 was indicated by the increase in filterer-collectors and decrease in relative abundance of Ephemeroptera (fig. 4), as well as by an increase in dominant taxon and decreases in Shannon diversity and relative abundance of intolerant macroinvertebrates (table 3). The cause for the decline between sites PR2 and PR3 is not known.

Macroinvertebrate communities in the middle reaches of the Powder River indicated decline in biological condition. The site pair bracketing Flying E Creek (site PR9-PR10) indicated decreases in relative abundance of Ephemeroptera, intolerant macroinvertebrates, and gatherer-collectors, and an increase in relative abundance of Diptera, all of which

Table 3. Macroinvertebrate community metrics, Powder River and Tongue River, Wyoming and Montana, 2010. $\left[\mathrm{m}^{2}\right.$, square meter; \%, percent]

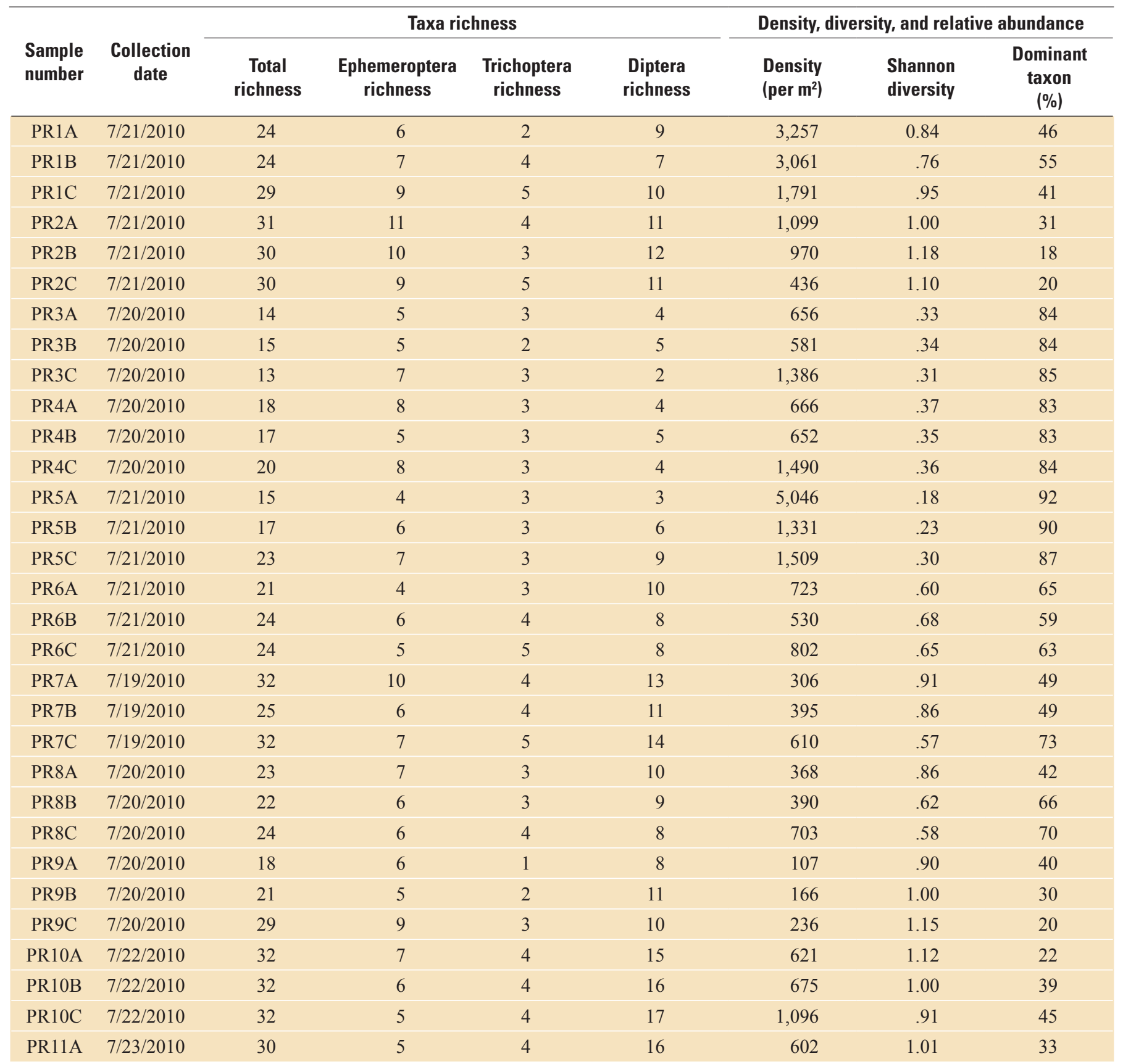


typically are associated with a decline in biological condition (Barbour and others, 1999). The site pair bracketing Wild Horse Creek (sites PR13-PR14) also indicated a decline in biological condition. Between sites PR13 and PR14, the relative abundance of intolerant macroinvertebrates and predators decreased, and Diptera relative abundance increased. Although sites PR12 and PR13 were not designed as a site pair (table 1), several metrics were significantly $(p<0.05)$ different between sites PR12 to PR13 (table 4) which bracket the influx of low specific-conductance water described earlier in this report. A decline in biological condition from sites PR12 to PR13 was indicated by increased abundance of filter-collectors and decreased abundance of predators, increase in dominant taxon percentage and decrease in Shannon diversity, and decrease in Diptera taxa richness and Chironomidae abundance. Chironomids including Saetheria and Cricotopus spp. were

Table 3. Macroinvertebrate community metrics, Powder River and Tongue River, Wyoming and Montana, 2010. - Continued $\left[\mathrm{m}^{2}\right.$, square meter; \%, percent]

\begin{tabular}{|c|c|c|c|c|c|c|c|c|}
\hline \multicolumn{4}{|c|}{ Density, diversity, and relative abundance } & \multicolumn{4}{|c|}{ Functional feeding groups } & \multirow{2}{*}{$\begin{array}{c}\text { Tolerance } \\
\begin{array}{c}\text { Intolerant } \\
(\%)\end{array}\end{array}$} \\
\hline $\begin{array}{c}\text { Ephemeroptera } \\
(\%)\end{array}$ & $\begin{array}{c}\text { Trichoptera } \\
(\%)\end{array}$ & $\begin{array}{c}\text { Diptera } \\
(\%)\end{array}$ & $\begin{array}{c}\text { Chironomidae } \\
(\%)\end{array}$ & $\begin{array}{c}\text { Predators } \\
(\%)\end{array}$ & $\begin{array}{l}\text { Gatherer- } \\
\text { collectors } \\
(\%)\end{array}$ & $\begin{array}{l}\text { Filterer- } \\
\text { collectors } \\
(\%)\end{array}$ & $\begin{array}{c}\text { Scrapers } \\
(\%)\end{array}$ & \\
\hline 26 & 18 & 52 & 6 & 1 & 27 & 69 & 1 & 32 \\
\hline 24 & 13 & 60 & 5 & 2 & 23 & 71 & 1 & 21 \\
\hline 27 & 19 & 52 & 8 & 2 & 33 & 62 & 2 & 25 \\
\hline 31 & 29 & 38 & 6 & 4 & 31 & 61 & 3 & 31 \\
\hline 36 & 30 & 29 & 14 & 6 & 43 & 43 & 3 & 35 \\
\hline 40 & 29 & 28 & 7 & 4 & 36 & 50 & 7 & 34 \\
\hline 11 & 3 & 85 & 1 & 0 & 9 & 91 & 0 & 12 \\
\hline 9 & 4 & 87 & 3 & 1 & 10 & 89 & 0 & 6 \\
\hline 7 & 8 & 85 & 0 & 0 & 6 & 94 & 0 & 11 \\
\hline 7 & 8 & 84 & 1 & 0 & 7 & 91 & 1 & 10 \\
\hline 8 & 7 & 84 & 1 & 0 & 8 & 91 & 0 & 10 \\
\hline 5 & 7 & 87 & 3 & 1 & 7 & 90 & 1 & 8 \\
\hline 1 & 5 & 93 & 1 & 0 & 3 & 97 & 0 & 5 \\
\hline 3 & 5 & 92 & 1 & 0 & 3 & 95 & 1 & 7 \\
\hline 2 & 8 & 89 & 2 & 1 & 3 & 94 & 1 & 8 \\
\hline 4 & 22 & 71 & 5 & 4 & 8 & 86 & 1 & 21 \\
\hline 4 & 25 & 67 & 7 & 3 & 9 & 83 & 2 & 21 \\
\hline 5 & 22 & 69 & 5 & 3 & 10 & 83 & 3 & 23 \\
\hline 10 & 12 & 72 & 22 & 6 & 24 & 60 & 6 & 19 \\
\hline 6 & 17 & 72 & 22 & 2 & 24 & 64 & 6 & 15 \\
\hline 4 & 12 & 81 & 8 & 4 & 9 & 81 & 4 & 12 \\
\hline 7 & 25 & 62 & 20 & 7 & 23 & 69 & 1 & 25 \\
\hline 6 & 13 & 77 & 11 & 2 & 14 & 82 & 2 & 14 \\
\hline 5 & 10 & 82 & 12 & 3 & 14 & 80 & 2 & 13 \\
\hline 27 & 9 & 56 & 48 & 6 & 68 & 23 & 2 & 33 \\
\hline 22 & 15 & 55 & 41 & 8 & 51 & 36 & 3 & 30 \\
\hline 25 & 22 & 40 & 27 & 15 & 41 & 35 & 7 & 41 \\
\hline 9 & 10 & 72 & 44 & 13 & 35 & 42 & 1 & 18 \\
\hline 8 & 7 & 81 & 38 & 7 & 27 & 57 & 1 & 17 \\
\hline 2 & 7 & 86 & 38 & 7 & 23 & 59 & 1 & 11 \\
\hline 3 & 8 & 82 & 47 & 8 & 31 & 44 & 2 & 11 \\
\hline
\end{tabular}


14 Assessment of Coalbed Natural Gas Development in Powder and Tongue Rivers, Wyoming and Montana, 2010

Table 3. Macroinvertebrate community metrics, Powder River and Tongue River, Wyoming and Montana, 2010. - Continued $\left[\mathrm{m}^{2}\right.$, square meter; \%, percent]

\begin{tabular}{|c|c|c|c|c|c|c|c|c|}
\hline \multirow[b]{2}{*}{$\begin{array}{l}\text { Sample } \\
\text { number }\end{array}$} & \multirow[b]{2}{*}{$\begin{array}{l}\text { Collection } \\
\text { date }\end{array}$} & \multicolumn{4}{|c|}{ Taxa richness } & \multicolumn{3}{|c|}{ Density, diversity, and relative abundance } \\
\hline & & $\begin{array}{c}\text { Total } \\
\text { richness }\end{array}$ & $\begin{array}{l}\text { Ephemeroptera } \\
\text { richness }\end{array}$ & $\begin{array}{l}\text { Trichoptera } \\
\text { richness }\end{array}$ & $\begin{array}{l}\text { Diptera } \\
\text { richness }\end{array}$ & $\begin{array}{l}\text { Density } \\
\left(\text { per } \mathrm{m}^{2}\right)\end{array}$ & $\begin{array}{l}\text { Shannon } \\
\text { diversity }\end{array}$ & $\begin{array}{c}\text { Dominant } \\
\text { taxon } \\
(\%)\end{array}$ \\
\hline PR11B & $7 / 23 / 2010$ & 35 & 7 & 5 & 16 & 1,336 & .87 & 47 \\
\hline PR11C & 7/23/2010 & 35 & 7 & 5 & 16 & 723 & 1.11 & 24 \\
\hline PR12A & $7 / 26 / 2010$ & 29 & 4 & 4 & 16 & 364 & 1.01 & 36 \\
\hline PR12B & $7 / 26 / 2010$ & 32 & 5 & 5 & 15 & 808 & .92 & 34 \\
\hline PR12C & $7 / 26 / 2010$ & 27 & 2 & 3 & 15 & 1,028 & 1.00 & 38 \\
\hline PR13A & $7 / 22 / 2010$ & 23 & 6 & 3 & 10 & 1,762 & .62 & 69 \\
\hline PR13B & $7 / 22 / 2010$ & 23 & 7 & 5 & 8 & 1,726 & .46 & 79 \\
\hline PR13C & $7 / 22 / 2010$ & 25 & 6 & 4 & 11 & 1,317 & .67 & 68 \\
\hline PR14A & $7 / 22 / 2010$ & 17 & 4 & 4 & 5 & 2,010 & .31 & 85 \\
\hline PR14B & $7 / 22 / 2010$ & 18 & 6 & 3 & 7 & 2,609 & .27 & 89 \\
\hline PR14C & $7 / 22 / 2010$ & 17 & 5 & 2 & 6 & 3,173 & 0.21 & 91 \\
\hline PR15A & $7 / 27 / 2010$ & 35 & 8 & 5 & 15 & 350 & 1.20 & 26 \\
\hline PR15B & $7 / 27 / 2010$ & 26 & 7 & 2 & 13 & 398 & 1.19 & 17 \\
\hline PR15C & $7 / 27 / 2010$ & 29 & 7 & 2 & 15 & 570 & 1.19 & 19 \\
\hline PR16A & $7 / 27 / 2010$ & 25 & 11 & 5 & 4 & 2,334 & .84 & 37 \\
\hline PR16B & $7 / 27 / 2010$ & 22 & 9 & 4 & 4 & 2,284 & .84 & 39 \\
\hline PR16C & 7/27/2010 & 16 & 6 & 4 & 2 & 2,245 & .81 & 36 \\
\hline PR17A & $7 / 28 / 2010$ & 21 & 8 & 5 & 3 & 2,654 & .76 & 40 \\
\hline PR17B & $7 / 28 / 2010$ & 20 & 8 & 5 & 3 & 1,901 & .77 & 38 \\
\hline PR17C & $7 / 28 / 2010$ & 21 & 9 & 5 & 2 & 2,761 & .76 & 35 \\
\hline PR18A & $7 / 28 / 2010$ & 24 & 10 & 4 & 4 & 328 & .93 & 30 \\
\hline PR18B & $7 / 28 / 2010$ & 16 & 7 & 2 & 2 & 210 & .79 & 38 \\
\hline PR18C & $7 / 28 / 2010$ & 25 & 10 & 3 & 6 & 268 & .80 & 36 \\
\hline TR1A & $9 / 13 / 2010$ & 29 & 7 & 6 & 7 & 11,086 & .98 & 29 \\
\hline TR1B & 9/13/2010 & 29 & 8 & 5 & 9 & 7,978 & 1.05 & 19 \\
\hline TR1C & $9 / 13 / 2010$ & 24 & 5 & 6 & 8 & 6,256 & .97 & 25 \\
\hline TR2A & 9/14/2010 & 37 & 8 & 8 & 11 & 6,630 & 1.20 & 21 \\
\hline TR2B & $9 / 14 / 2010$ & 34 & 7 & 7 & 10 & 6,896 & 1.20 & 17 \\
\hline TR2C & 9/14/2010 & 31 & 8 & 6 & 6 & 10,045 & 1.11 & 24 \\
\hline TR3A & $9 / 14 / 2010$ & 32 & 8 & 7 & 8 & 5,878 & 1.15 & 25 \\
\hline TR3B & $9 / 14 / 2010$ & 38 & 8 & 7 & 14 & 7,198 & 1.25 & 17 \\
\hline TR3C & 9/14/2010 & 34 & 7 & 8 & 11 & 6,825 & 1.19 & 22 \\
\hline TR4A & 9/16/2010 & 36 & 6 & 7 & 13 & 15,447 & 1.11 & 30 \\
\hline TR4B & $9 / 16 / 2010$ & 40 & 8 & 6 & 16 & 12,447 & 1.12 & 29 \\
\hline TR4C & 9/16/2010 & 31 & 9 & 5 & 10 & 10,577 & 1.11 & 28 \\
\hline TR5A & $9 / 15 / 2010$ & 30 & 6 & 7 & 10 & 8,064 & 1.13 & 23 \\
\hline TR5B & $9 / 15 / 2010$ & 35 & 5 & 9 & 14 & 11,921 & 1.10 & 32 \\
\hline TR5C & $9 / 15 / 2010$ & 35 & 7 & 7 & 11 & 14,194 & 1.13 & 28 \\
\hline TR6A & $9 / 15 / 2010$ & 35 & 7 & 8 & 13 & 2,360 & 1.17 & 16 \\
\hline TR6B & $9 / 15 / 2010$ & 30 & 7 & 8 & 10 & 3,556 & 1.09 & 24 \\
\hline TR6C & $9 / 15 / 2010$ & 33 & 7 & 7 & 12 & 6,766 & 1.13 & 18 \\
\hline
\end{tabular}


Table 3. Macroinvertebrate community metrics, Powder River and Tongue River, Wyoming and Montana, 2010.—Continued [ $\mathrm{m}^{2}$, square meter; $\%$, percent]

\begin{tabular}{|c|c|c|c|c|c|c|c|c|}
\hline \multicolumn{4}{|c|}{ Density, diversity, and relative abundance } & \multicolumn{4}{|c|}{ Functional feeding groups } & \multirow{2}{*}{$\begin{array}{c}\text { Tolerance } \\
\begin{array}{c}\text { Intolerant } \\
(\%)\end{array}\end{array}$} \\
\hline $\begin{array}{c}\text { Ephemeroptera } \\
(\%)\end{array}$ & $\begin{array}{c}\text { Trichoptera } \\
(\%)\end{array}$ & $\begin{array}{l}\text { Diptera } \\
(\%)\end{array}$ & $\begin{array}{c}\text { Chironomidae } \\
(\%)\end{array}$ & $\begin{array}{c}\text { Predators } \\
(\%)\end{array}$ & $\begin{array}{l}\text { Gatherer- } \\
\text { collectors } \\
(\%)\end{array}$ & $\begin{array}{c}\text { Filterer- } \\
\text { collectors } \\
(\%)\end{array}$ & $\begin{array}{c}\text { Scrapers } \\
(\%)\end{array}$ & \\
\hline 4 & 6 & 86 & 38 & 4 & 29 & 56 & 2 & 9 \\
\hline 8 & 12 & 71 & 44 & 11 & 40 & 40 & 2 & 18 \\
\hline 6 & 11 & 76 & 31 & 15 & 27 & 48 & 3 & 11 \\
\hline 4 & 5 & 87 & 48 & 9 & 37 & 41 & 1 & 8 \\
\hline 4 & 10 & 80 & 38 & 8 & 24 & 52 & 1 & 12 \\
\hline 13 & 8 & 76 & 7 & 2 & 15 & 78 & 0 & 19 \\
\hline 12 & 6 & 81 & 1 & 2 & 12 & 84 & 0 & 17 \\
\hline 14 & 8 & 75 & 7 & 2 & 17 & 76 & 1 & 21 \\
\hline 11 & 2 & 87 & 2 & 0 & 12 & 87 & 0 & 11 \\
\hline 5 & 1 & 93 & 5 & 0 & 7 & 91 & 0 & 7 \\
\hline 6 & 1 & 92 & 1 & 0 & 6 & 93 & 1 & 7 \\
\hline 48 & 20 & 22 & 18 & 12 & 59 & 16 & 4 & 53 \\
\hline 36 & 27 & 32 & 24 & 5 & 54 & 26 & 1 & 42 \\
\hline 39 & 19 & 36 & 28 & 7 & 60 & 22 & 1 & 42 \\
\hline 30 & 27 & 38 & 0 & 1 & 32 & 64 & 2 & 52 \\
\hline 33 & 23 & 40 & 1 & 1 & 34 & 61 & 3 & 49 \\
\hline 31 & 27 & 36 & 0 & 1 & 34 & 63 & 2 & 46 \\
\hline 34 & 22 & 41 & 0 & 1 & 33 & 63 & 3 & 51 \\
\hline 32 & 25 & 38 & 0 & 1 & 32 & 64 & 2 & 53 \\
\hline 25 & 37 & 35 & 0 & 1 & 24 & 71 & 2 & 55 \\
\hline 41 & 16 & 38 & 13 & 4 & 52 & 41 & 2 & 52 \\
\hline 39 & 14 & 41 & 3 & 2 & 41 & 52 & 3 & 44 \\
\hline 49 & 10 & 38 & 1 & 1 & 47 & 46 & 5 & 54 \\
\hline 38 & 20 & 31 & 1 & 1 & 44 & 49 & 6 & 51 \\
\hline 44 & 23 & 21 & 3 & 1 & 52 & 41 & 4 & 58 \\
\hline 40 & 18 & 30 & 5 & 2 & 50 & 42 & 2 & 43 \\
\hline 27 & 30 & 9 & 5 & 4 & 50 & 14 & 21 & 71 \\
\hline 30 & 33 & 12 & 3 & 3 & 43 & 30 & 15 & 66 \\
\hline 34 & 33 & 10 & 5 & 2 & 50 & 36 & 8 & 70 \\
\hline 36 & 26 & 16 & 11 & 2 & 49 & 14 & 23 & 65 \\
\hline 30 & 30 & 15 & 11 & 2 & 46 & 22 & 17 & 64 \\
\hline 31 & 30 & 14 & 8 & 6 & 48 & 25 & 13 & 67 \\
\hline 51 & 12 & 28 & 25 & 3 & 64 & 15 & 1 & 35 \\
\hline 50 & 12 & 32 & 29 & 2 & 60 & 16 & 2 & 33 \\
\hline 54 & 15 & 25 & 20 & 1 & 65 & 19 & 3 & 38 \\
\hline 41 & 31 & 15 & 11 & 4 & 53 & 30 & 6 & 61 \\
\hline 47 & 18 & 16 & 9 & 6 & 61 & 20 & 9 & 70 \\
\hline 51 & 25 & 8 & 4 & 6 & 63 & 18 & 7 & 75 \\
\hline 45 & 23 & 17 & 9 & 3 & 55 & 28 & 8 & 54 \\
\hline 49 & 15 & 16 & 5 & 3 & 62 & 22 & 10 & 66 \\
\hline 37 & 28 & 11 & 6 & 3 & 57 & 30 & 5 & 69 \\
\hline
\end{tabular}


relatively abundant at site PR12, as well as at sites PR7-PR11 and PR15. Saetheria is a gatherer-collector, and the Cricotopus spp. identified are shredders and omnivores (Merritt and Cummins, 1996; Cuffney, 2003), which contributes to the difference in relative abundance among functional feeding groups at sites PR12 and PR13. Two site pairs (PR10-PR11, and PR10-PR12) in the middle reaches of the Powder River indicated no significant differences in metric values. Those site pairs were designed to bracket Barber Creek and other effluent downstream of Barber Creek.
Macroinvertebrate communities in the lower reaches of the Powder River indicated either increase in biological condition or no change. At sites PR14-PR15 that bracket unidentified effluents, more than a dozen metrics were significantly different $(\mathrm{p}<0.05)$ between the sites (table 4$)$, including an increase in relative abundance of Ephemeroptera and decrease in filterer-collectors (fig. 4). The average relative abundance of intolerant macroinvertebrates was 8 percent at site PR14 and 46 percent at site PR15. Other metrics that were significantly different between sites PR14 and PR15 were increases in total

Table 4. Analysis of variance for macroinvertebrate community metrics, Powder River and Tongue River, Wyoming and Montana, 2010.

[ --, difference in metric value between sites not significant at $\mathrm{p}=0.05 ; \mathrm{D}$, significant decrease in metric value, I, significant increase in metric value; NA, not analyzed (group $\mathrm{p}>0.05$ ); ${ }^{*}$, results based on a Wilcoxon rank sum test]

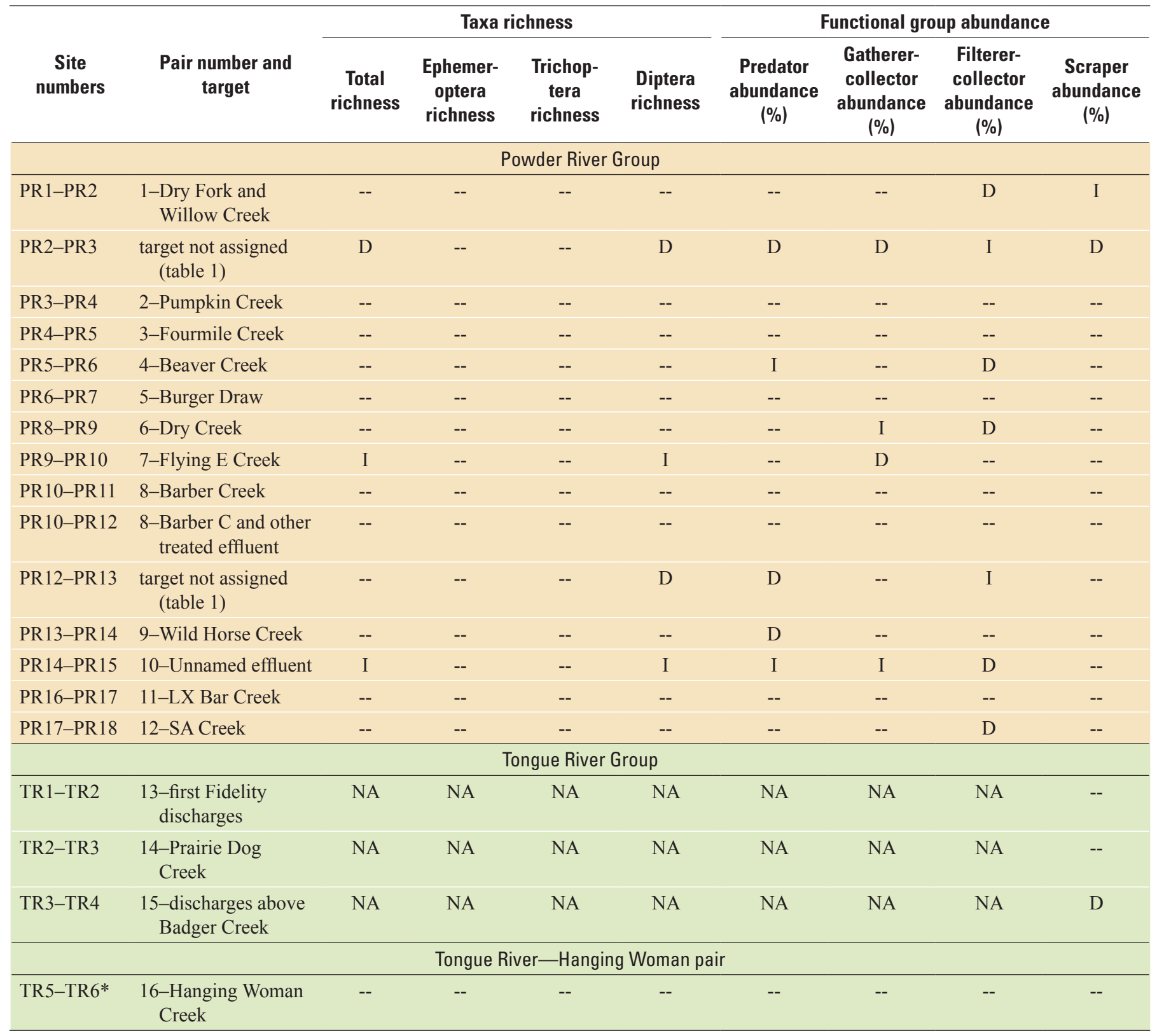


richness, Diptera richness, Shannon diversity, and relative abundance of predators, collector-gatherers, Trichoptera, and Chironomidae, and decreases in density, dominant taxon, and Diptera abundance due to few Simulium spp. individuals. At sites PR17-PR18 that bracket SA Creek, biological condition appeared to increase between the sites on the basis of decreases in filterer-collector abundance and density, and increases in abundance of Ephemeroptera and Chironomidae. The site pair that brackets LX Bar Creek (PR16-PR17) indicated no significant changes in metric values.

Table 4. Analysis of variance for macroinvertebrate community metrics, Powder River and Tongue River, Wyoming and Montana, 2010.-Continued

[ --, difference in metric value between sites not significant at $\mathrm{p}=0.05 ; \mathrm{D}$, significant decrease in metric value, I, significant increase in metric value; NA, not analyzed (group $\mathrm{p}>0.05$ ); ${ }^{*}$, results based on a Wilcoxon rank sum test]

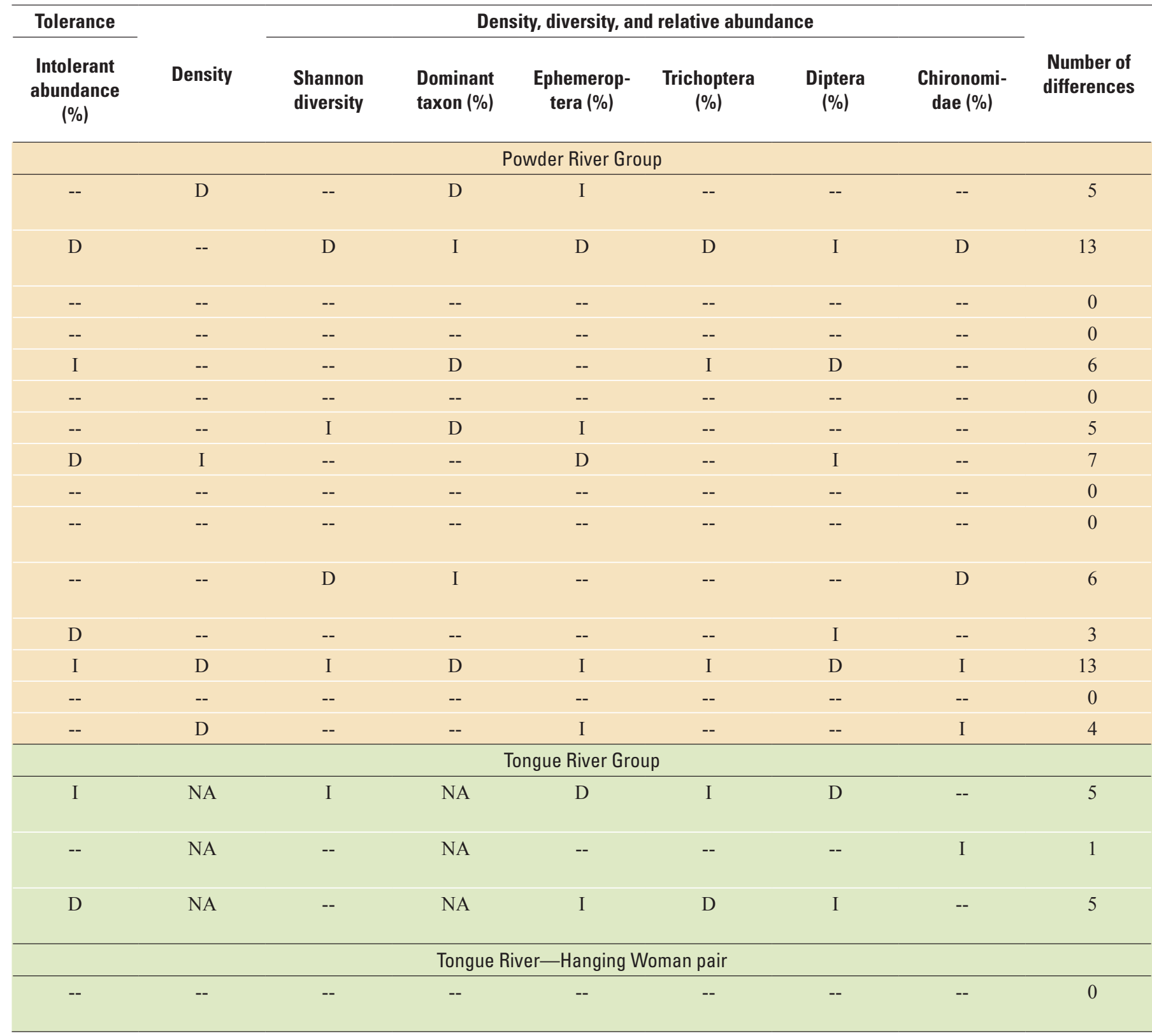



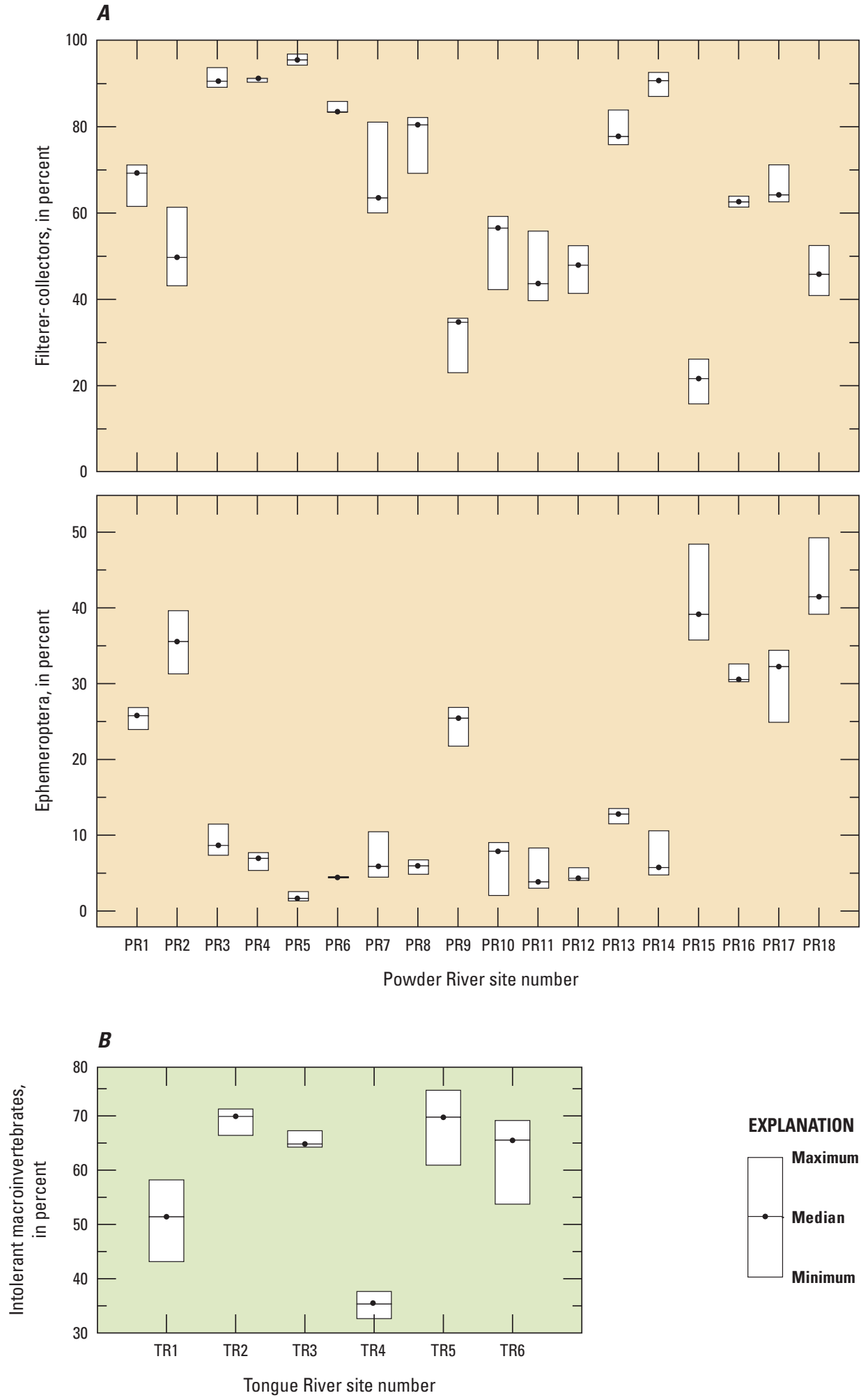

EXPLANATION

Figure 4. Selected macroinvertebrate community metrics from ecological sampling sites, $A$, Powder River and B, Tongue River, Wyoming and Montana, 2010. 


\section{Observed/Expected Model}

Biological condition, as evaluated with the Wyoming invertebrate observed/expected (O/E) model, was significantly different among sites on the mainstem Powder River (ratio of sample variances $F=5.19, p<0.0001$ ). According to the Tukey multiple-comparison rank test, $\mathrm{O} / \mathrm{E}$ scores were lowest at sites PR1 $($ mean $=0.31)$ and PR14 $($ mean $=0.37)$ whereas scores were highest at sites PR2, PR4, PR6, PR7, PR10, PR11, PR15, PR16 and PR18 (mean $=0.75$ ) relative to all other sites (table 5). Considering the naturally variable environmental conditions of plains streams such as the Powder River, the variability of the mean $\mathrm{O} / \mathrm{E}$ scores at each site was very low at \pm 0.06 , based on the root mean square error (RMSE) for a 90 percent confidence interval (Zar, 1984). Intra-sample precision was less than that of the Wyoming O/E model of \pm 0.17 , which is precise enough to detect even modest anthropogenic disturbance.

A wide range in $\mathrm{O} / \mathrm{E}$ scores was apparent among Powder River sites (fig. 5). Interspersed within this variability, however, were three localized reaches that each displayed a decrease preceded by an abrupt increase in biological condition. Biological condition, as described by $\mathrm{O} / \mathrm{E}$ scores, increased from PR1 to PR2, followed by a spatially variable yet general decline from PR2 to PR9. A second appreciable increase in biological condition occurred between PR9 and PR10, followed by the most precipitous and cumulative downstream decline in biological condition along the Powder River from PR10 to PR14. Finally, there was an abrupt increase in biological condition from PR14 to PR15, followed by a marginal downstream decline from PR15 to PR17. Contributions from major tributaries to the Powder River such as Crazy Woman and Clear Creeks did not appear to be responsible for any of the four appreciable increases in biological condition. In fact, the sites that exhibited abrupt increases in biological condition each occurred immediately below smaller tributaries such as Willow Creek (PR2), Burger Draw (PR7), Flying E Creek (PR10), and Joe Creek (PR15).

The uppermost and lowermost sites within each declining biological-condition segment, particularly the PR10-PR14 and PR2-PR9 segments, corresponded to some of the highest and lowest $\mathrm{O} / \mathrm{E}$ scores according to the Tukey multiple comparison rank test. Biological condition declined by 52 percent, 34 percent, and 15 percent from the upstream to downstream extents within the PR10-PR14, PR2-PR9 and PR15-PR17 segments, respectively. The variable but overall decline in biological condition within the PR2-PR9 segment indicates localized noncumulative environmental stressors influenced the resident biota. This may indicate localized perturbations were spatially limited in their extent and/or the declines were offset by other factors such as tributary contributions. Localized biological condition declines within the PR2-PR9 segment occurred above Pumpkin Creek (PR3), below Fourmile Creek (PR5), and above Dry Creek (PR8). Localized increases in biological condition occurred at sites PR4 (below Pumpkin Creek) and PR7 (below Burger Draw). The declining trend in biological condition within the remaining two segments, in particular segment PR10-PR14, indicates the macroinvertebrate communities were subjected to additive effects of environmental stressors with distance downstream. Cumulative inputs from smaller tributaries such as Fortification and Wild Horse Creeks may contribute to the biological-condition declines within those two remaining segments. An absence of expected mayfly (Ephemeroptera), beetle (Coleoptera), midge (Diptera) and non-insect taxa, among other groups, that were predicted to occur with a probability greater than 50 percent, contributed to the measured declines in biological condition within these four segments of the Powder River. Absence of non-insect water mites (Acari) and the moderately tolerant mayfly Tricorythodes played a large role in the decline in the measured biological condition between sites PR10 and PR14. An absence of the mayflies Baetis and Tricorythodes, riffle beetles Microcylloepus and Dubiraphia, and/or the tolerant midge Rheotanytarsus relative to the macroinvertebrate community at site PR2 indicated a general downstream decline in biological condition within the PR2-PR9 segment. Lastly, the marginal downstream decline in biological condition within the PR15-PR17 segment was associated with the disappearance of Dubiraphia and to some extent the mayflies Caenis and Baetis, and in particular Tricorythodes, that are considered ubiquitous generalists tolerant to a wide range of environmental stressors but preferring waters with sufficient dissolved oxygen, low to moderate nutrient concentrations, and low to moderate organic enrichment (Barbour and others, 1999; Ward, 1992; Winget and Magnum, 1991). Tricorythodes and Baetis generally inhabit stable gravel- or sand-dominated channels; are a common component of the macroinvertebrate community in plains streams with naturally large sediment loads; and in the case of Tricorythodes, may thrive in waters with low to moderate levels of human disturbance such as during or after periods of increased suspended or accumulated sediment (Gray and Ward 1982; Peterson 1990; Ward 1986; Ward 1992). Loss of Baetis, and in particular Tricorythodes, within the PR10-PR14 and PR2-PR9 segments was unexpected considering their tolerances to naturally high sediment loads and preferences for fine-gravel/sand-dominated channel beds of the Powder River. Caenis are widespread collectorgatherers adapted to residing in fine-sediment-dominated habitats, but they are considered to be moderately sensitive to environmental stressors (Merritt and Cummins, 1996; Ward, 1992). Although they generally exhibit patchy distributions within stream microhabitats, the decline of Caenis within the PR15-PR17 segment is puzzling considering preferable physical habitat conditions for this taxon within the segment. Microcylloepus and Dubiraphia are associated with lentic and lotic habitats, though Dubiraphia has been shown to decrease in relative abundance with increased human disturbance (Elliott and others, 1997; Merritt and Cummins, 1996). The downstream disappearance of Acari within the PR10-PR14 segment was surprising as this arthropod commonly occurs across a broad ecological spectrum of streams. Environmental stress, however, can trigger diapause in Acari and many 
Table 5. Observed/expected scores and analysis of variance among mean scores for macroinvertebrate communities, Powder River and Tongue River, Wyoming and Montana, 2010.

[O, observed; E, expected; BC, Bray-Curtis index; Tukey, analysis of variance with Tukey test, letters indicate significant (p $<0.05$ ) differences in mean O/E scores between sites within Powder River and Tongue River groups]

\begin{tabular}{|c|c|c|c|c|c|c|c|}
\hline $\begin{array}{l}\text { Sample } \\
\text { number }\end{array}$ & 0 & $\mathbf{E}$ & $0 / E$ & Mean 0/E & Tukey & BC & Mean BC \\
\hline \multicolumn{8}{|c|}{ Powder River Group } \\
\hline PR1 & 3 & 14 & 0.21 & 0.31 & $\mathrm{C}$ & 0.74 & 0.64 \\
\hline PR1 & 5 & 14 & .36 & & & .59 & \\
\hline PR1 & 5 & 14 & .36 & & & .59 & \\
\hline PR2 & 7 & 9 & .78 & .85 & A & .27 & .24 \\
\hline PR2 & 9 & 9 & 1.00 & & & .18 & \\
\hline PR2 & 7 & 9 & .78 & & & .28 & \\
\hline PR3 & 6 & 9 & .67 & .59 & B & .37 & .40 \\
\hline PR3 & 6 & 9 & .67 & & & .35 & \\
\hline PR3 & 4 & 9 & .44 & & & .48 & \\
\hline PR4 & 7 & 9 & .78 & .78 & A & .28 & .28 \\
\hline PR4 & 6 & 9 & .67 & & & .35 & \\
\hline PR4 & 8 & 9 & .89 & & & .21 & \\
\hline PR5 & 4 & 9 & .44 & .56 & B & .52 & .41 \\
\hline PR5 & 6 & 9 & .67 & & & .33 & \\
\hline PR5 & 5 & 9 & .56 & & & .39 & \\
\hline PR6 & 7 & 9 & .78 & .67 & A & .27 & .34 \\
\hline PR6 & 6 & 9 & .67 & & & .33 & \\
\hline PR6 & 5 & 9 & .56 & & & .43 & \\
\hline PR7 & 7 & 9 & .78 & .85 & A & .30 & .25 \\
\hline PR7 & 9 & 9 & 1.00 & & & .15 & \\
\hline PR7 & 7 & 9 & .78 & & & .30 & \\
\hline PR8 & 5 & 9 & .56 & .60 & B & .41 & .38 \\
\hline PR8 & 6 & 9 & .67 & & & .33 & \\
\hline PR8 & 5 & 9 & .56 & & & .41 & \\
\hline PR9 & 4 & 9 & .44 & .56 & B & .52 & .42 \\
\hline PR9 & 5 & 9 & .56 & & & .41 & \\
\hline PR9 & 6 & 9 & .67 & & & .33 & \\
\hline PR10 & 8 & 9 & .89 & .78 & A & .21 & .27 \\
\hline PR10 & 7 & 9 & .78 & & & .27 & \\
\hline PR10 & 6 & 9 & .67 & & & .33 & \\
\hline PR11 & 6 & 9 & .67 & .71 & A & .35 & .32 \\
\hline PR11 & 6 & 9 & .67 & & & .33 & \\
\hline PR11 & 7 & 9 & .78 & & & .27 & \\
\hline PR12 & 6 & 9 & .67 & .63 & B & .33 & .36 \\
\hline PR12 & 6 & 9 & .67 & & & .33 & \\
\hline PR12 & 5 & 9 & .56 & & & .41 & \\
\hline PR13 & 4 & 9 & .44 & .56 & B & .44 & .38 \\
\hline
\end{tabular}


Table 5. Observed/expected scores and analysis of variance among mean scores for macroinvertebrate communities, Powder River and Tongue River, Wyoming and Montana, 2010._- Continued

[O, observed; E, expected; BC, Bray-Curtis index; Tukey, analysis of variance with Tukey test, letters indicate significant ( $\mathrm{p}$ $<0.05$ ) differences in mean O/E scores between sites within Powder River and Tongue River groups]

\begin{tabular}{|c|c|c|c|c|c|c|c|}
\hline $\begin{array}{l}\text { Sample } \\
\text { number }\end{array}$ & 0 & $\mathbf{E}$ & O/E & Mean 0/E & Tukey & BC & Mean BC \\
\hline \multicolumn{8}{|c|}{ Powder River Group-Continued } \\
\hline PR13 & 5 & 9 & 0.56 & & & 0.36 & \\
\hline PR13 & 6 & 9 & .67 & & & .33 & \\
\hline PR14 & 5 & 9 & .56 & 0.37 & $\mathrm{C}$ & .36 & 0.56 \\
\hline PR14 & 1 & 9 & .11 & & & .85 & \\
\hline PR14 & 4 & 9 & .44 & & & .46 & \\
\hline PR15 & 7 & 9 & .78 & .74 & A & .25 & .29 \\
\hline PR15 & 6 & 9 & .67 & & & .35 & \\
\hline PR15 & 7 & 9 & .78 & & & .27 & \\
\hline PR16 & 6 & 9 & .67 & .67 & A & .30 & .29 \\
\hline PR16 & 7 & 9 & .78 & & & .22 & \\
\hline PR16 & 5 & 9 & .56 & & & .36 & \\
\hline PR17 & 5 & 9 & .56 & .63 & B & .39 & .33 \\
\hline PR17 & 6 & 9 & .67 & & & .30 & \\
\hline PR17 & 6 & 9 & .67 & & & .30 & \\
\hline PR18 & 7 & 9 & .78 & .74 & A & .28 & .28 \\
\hline PR18 & 7 & 9 & .78 & & & .22 & \\
\hline PR18 & 6 & 9 & .67 & & & .35 & \\
\hline \multicolumn{8}{|c|}{ Tongue River Group } \\
\hline TR1 & 1 & 7 & 0.14 & 0.32 & $\mathrm{~B}$ & 0.76 & 0.59 \\
\hline TR1 & 2 & 7 & .28 & & & .61 & \\
\hline TR1 & 4 & 7 & .55 & & & .41 & \\
\hline TR2 & 6 & 7 & .82 & .68 & A & .33 & .38 \\
\hline TR2 & 5 & 7 & .68 & & & .38 & \\
\hline TR2 & 4 & 7 & .55 & & & .43 & \\
\hline TR3 & 6 & 8 & .80 & .76 & A & .33 & .35 \\
\hline TR3 & 5 & 8 & .67 & & & .39 & \\
\hline TR3 & 6 & 8 & .80 & & & .33 & \\
\hline TR4 & 6 & 8 & .79 & .70 & A & .31 & .34 \\
\hline TR4 & 5 & 8 & .66 & & & .36 & \\
\hline TR4 & 5 & 8 & .66 & & & .35 & \\
\hline TR5 & 4 & 8 & .50 & .54 & $\mathrm{AB}$ & .42 & .40 \\
\hline TR5 & 4 & 8 & .50 & & & .42 & \\
\hline TR5 & 5 & 8 & .63 & & & .36 & \\
\hline TR6 & 4 & 8 & .50 & .50 & $\mathrm{AB}$ & .42 & .44 \\
\hline TR6 & 3 & 8 & .38 & & & .53 & \\
\hline TR6 & 5 & 8 & .63 & & & .36 & \\
\hline
\end{tabular}



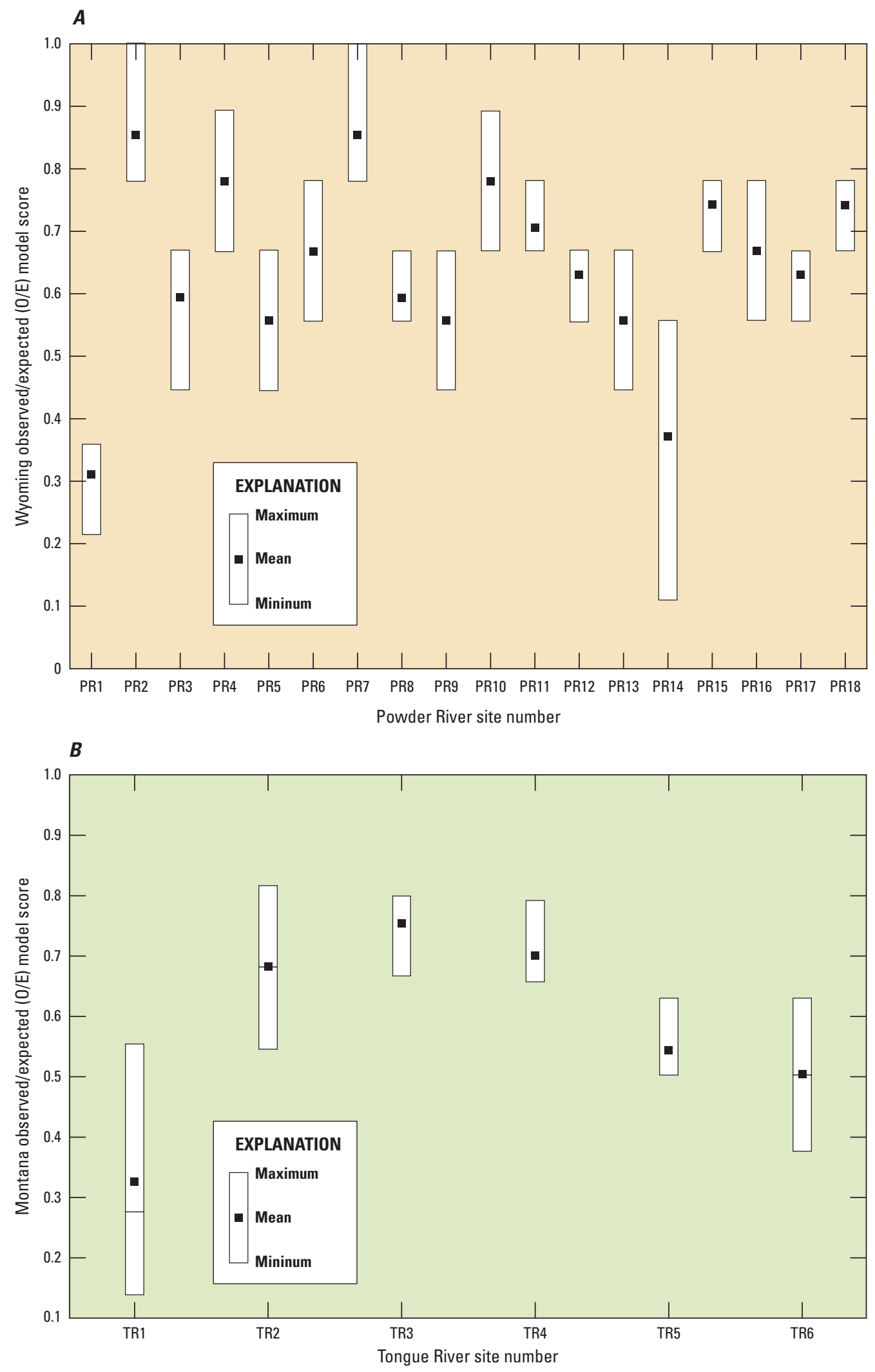

Figure 5. Macroinvertebrate observed/expected model scores from ecological sampling sites, $A$, Powder River and B, Tongue River, Wyoming and Montana, 2010. 
insects that could translate to a decline or absence within the sampled community.

Similarities to an expected reference condition as measured by the $\mathrm{BC}$ index also differed significantly among Powder River sites $(\mathrm{F}=3.99, \mathrm{p}<0.001)$ with a spatial pattern opposite that of the $\mathrm{O} / \mathrm{E}$ scores. The most downstream sites of segments PR2-PR9, PR10-PR14 and PR15-PR17 were more dissimilar (higher BC scores) from reference than the upstream sites on those segments. This indicates greater taxa replacement with distance downstream within each of the three segments. Sites PR1 (mean $=0.64)$ and PR14 (mean $=0.56)$ were the most dissimilar from reference conditions relative to all other sites on the Powder River. In other words, 64 percent and 56 percent of the taxa collected at PR1 and PR14, respectively, replaced those expected to occur at these sites according to the model.

The macroinvertebrate communities at PR1 and the most downstream sites within the PR2-PR9, PR10-PR14, and to a lesser extent the PR15-PR17 segments, were dominated by high percentages of collector-filterer and collector-gatherer taxa with moderate to high tolerances to environmental stressors. These taxa included midges such as Saetheria sp.; black flies (Simulium sp.); and Hydropsyche caddisfly larvae. Dominance of these taxa contributed to the lower $\mathrm{O} / \mathrm{E}$ and higher $\mathrm{BC}$ scores at PR1 and at the downstream sites on each of the three segments. One anomaly to the dominance of tolerant taxa at the downstream sites was the relatively high abundance of the clinger mayfly Traverella sp., considered sensitive to environmental stressors, at PR17. Its high relative abundance likely was associated with the coarser riffle substrate relative to other Powder River sites. In addition, its presence reflects the marginal decline in biological condition within the PR15-PR17 segment relative to the more pronounced downstream decreases in biological condition displayed in the other two segments. Collectively, the overall spatial patterns in biological condition in 2010 are similar to what was reported by Peterson and others $(2009 ; 2010)$ within the same general reaches of the Powder River.

\section{Tongue River}

\section{Community Metrics}

Macroinvertebrate community metrics indicated a general increase in biological condition from site TR1, near the Wyoming-Montana border, to site TR2 that is downstream of CBNG-produced water discharges in Montana. From site TR1 to TR2, increases were noted in Shannon diversity and relative abundance of intolerant macroinvertebrates (fig. 4) and Trichoptera, and a decrease was noted in relative abundance of Diptera (table 4). The relative abundance of Ephemeroptera decreased, however, from an average of 41 percent at site TR1 to 31 percent at site TR2. Despite the marginal decline, Ephemeroptera still constituted a substantial portion of the community at site TR2 (table 3 ) indicating minimal effects due to CBNG. Sites TR2 and TR3 are upstream and downstream of Prairie Dog Creek, which is a major tributary to the Tongue River and receives discharges from CBNG production and irrigation-return flows. Among all evaluated metrics, only the relative abundance of Chironomidae increased significantly (albeit marginally) between sites TR2 and TR3 (table 4).

Community metrics generally indicated a decline in biological condition between sites TR3 and TR4, from downstream of Prairie Dog Creek to upstream of Badger Creek. The relative abundance of scrapers, intolerant macroinvertebrates, and Trichoptera decreased from site TR3 to TR4, whereas the relative abundance of Ephemeroptera and Diptera increased, all of which were statistically significant (table 4). The dominant taxon shifted from Fallceon quilleri (average 21 percent) at site TR3 to Tricorythodes (average 29 percent) at site TR4, which helps explain the marginal increase in relative abundance of Ephemeroptera between the sites.

None of the community metrics were significantly different between sites TR5 and TR6, upstream and downstream of Hanging Woman Creek (table 4). The lack of significant differences was not surprising, given that these sites were sampled to establish a measure of baseline conditions in anticipation of future development.

\section{Observed/Expected Model}

The Montana O/E model indicated the biological condition varied significantly between Tongue River sites $(\mathrm{F}=4.84$, $\mathrm{p}<0.05$; table 5). Site TR1 had the lowest overall scores, which were significantly different from scores at all other Tongue River sites (fig. 5, table 5). The O/E scores substantially increase at TR2 (above Prairie Dog Creek; mean $=0.68$ ), with a slight increase at site TR3 (below Prairie Dog Creek; mean $=0.76$ ), followed by a decrease at TR4 (above Badger Creek; mean $=0.70$ ). Downstream of the Tongue River Reservoir, sites TR5 (above Hanging Woman Creek; mean $=0.54$ ) and TR6 (below Hanging Woman Creek; mean $=0.50$ ) scored slightly lower than the TR2 to TR4 group and scored slightly higher than the values from samples collected at site TR1. Scores at sites TR5 and TR6 were not significantly different from any of the other Tongue River sites. These data indicate that CBNG discharges do not substantially affect biological condition on the mainstem Tongue River. The variability of the samples was very low $(\mathrm{RMSE}=0.07)$. This is much lower than the error for the Montana O/E model $( \pm 0.17)$.

The $\mathrm{BC}$ index scores for the samples collected on the Tongue River followed a trend opposite that to the O/E scores (Table 5). The samples collected from site TR1 were the most dissimilar from reference $($ mean $=0.59)$. This shows that the majority ( 60 percent) of the taxa collected from TR1 replaced those taxa expected to be there by the model. The average dissimilarity decreased between sites TR2, TR3, and TR4 (means $=0.38,0.35$, and 0.34 , respectively). The BC scores trended upward from sites TR5 and TR6 (means $=0.40$, and 0.44 , respectively). The changes in $\mathrm{BC}$ scores demonstrated the effect of taxa replacement on the $\mathrm{O} / \mathrm{E}$ results. Taxa collected from some of the Tongue River sites varied 
substantially from each other. For example, all of the samples collected from TR1 were dominated by Simulium sp. and Acarina. These taxa were not expected by the $\mathrm{O} / \mathrm{E}$ model, and therefore $\mathrm{O} / \mathrm{E}$ scores were significantly lower than the others. Sites TR2 through TR4 were either dominated by Microcylloepus, Fallceon, or Tricorythodes, respectively. The greater abundance of these sensitive taxa contributed to an increase in the $\mathrm{O} / \mathrm{E}$ scores, and a decrease in $\mathrm{BC}$ scores.

Communities at sites TR5 and TR6 were dominated by mayflies Fallceon, Microcylloepus, and net-spinning Hydropsychidae. The samples from TR5 and TR6 also contained Simulium sp. and water mites.

\section{Algal Communities}

Diatoms (Bacillariophyta) were the predominant phylum in algal communities of the Powder River and Tongue River (table 6), often comprising 90 percent or more of the identified taxa. A few blue-green cyanobacteria (Cyanophyta) and green algae (Chlorophyta) taxa generally were present in the samples. Though low in taxa richness, blue-green algae commonly dominated in terms of relative abundance. Aside from these general patterns, algal communities of the Powder River were substantially different from those of the Tongue River. For example, red algae (Rhodophyta) were absent from the Powder River but present at all Tongue River sites. Taxa richness was generally lower in the Powder River (average 36 taxa per sample) than the Tongue River (average 60 taxa per sample). The algal taxonomic data are available online at: http://wy.water.usgs.gov/projects/atg/htms/data.htm (accessed October 6, 2011).

\section{Powder River}

Blue-green algae dominated the algal communities of the Powder River, with an average relative abundance of 66 percent, compared to 33 percent diatoms and 1 percent green algae. Diatoms composed a majority of the taxa, however, with an average of 33 taxa per sample.

Algal community composition in the Powder River trended in the downstream direction but also varied between sites. For example, algal taxa richness and the Shannon diversity index generally increased in the downstream direction (fig. 6). Site-to-site variations in taxa richness and diversity also occurred that exceeded the standard deviation observed in split and replicate samples (table 6) and consequently could not be attributed to natural variation or error during sampling and analysis. The split and replicate sample data listed in table 6 were not used in data analysis except as specified.

In the upper to middle reaches of the Powder River, increases or decreases in taxa richness and diversity generally corresponded to increases or decreases in biological condition as indicated by the invertebrate communities. For example, algal taxa richness and diversity generally increased at sites PR1-PR2 (Dry Fork and Willow Creek), sites PR5-PR6 (Beaver Creek), and sites PR8-PR9 (Dry Creek), and decreased at sites PR2-PR3 (downstream of Willow Creek to upstream of Pumpkin Creek) and sites PR9-PR10 (Flying E Creek), which corresponded to invertebrate community changes in the same direction. Maximum values of algal taxa richness and diversity generally occurred at sites PR13-PR15 (fig. 6), coinciding with the inflow of low specific-conductance water and inflow from Crazy Woman Creek described earlier, but in contrast to a decrease in biological condition of the invertebrate communities. The occurrence of maximum values for taxa richness and diversity at sites PR13-PR15 might reflect disturbance under the intermediate disturbance hypothesis (Grime, 1973) whereby a disturbance (or perturbation) to the system causes species diversity to be higher than would be present at equilibrium.

Site-to-site increases and decreases in relative abundance of halophilic diatoms (those preferring high salinity) and facultative nitrogen heterotrophs (diatoms which need high levels of organic nitrogen) in the upper and middle reaches of the Powder River generally corresponded inversely to increases and decreases in algal taxa richness, diversity, and invertebrate community condition; abundances decreased in the downstream direction (fig. 6). For example, the relative abundance of halophilic diatoms and facultative nitrogen heterotrophic diatoms, which need periodically elevated concentrations of organic nitrogen, increased from sites PR2 to PR3 and PR12-PR13, whereas invertebrate community condition decreased at those site pairs. Obligate nitrogen heterotrophs, which need continuously elevated concentrations of organic nitrogen, composed less than 10 percent of the diatoms in the Powder River except at PR13-PR15 where they composed 16 to 24 percent (table 6 ) of the community, which might indicate the inflow of low specific-conductance water previously described also contains relatively high concentrations of organic nitrogen.

Alkaliphilic diatoms that prefer $\mathrm{pH}$ greater than 7 generally dominated the diatom communities of the Powder River. An exception was site PR17 below LX Bar C, where 64 percent were alkaliphilic and 28 percent circumneutral $(\mathrm{pH}$ near 7). This community may be an indicator of less-alkaline sources of water in the area.

Algal taxa in the Powder River were motile or adapted to living on unstable sediments associated with sedimentation (Porter, 2008). About 40 to 70 percent of the algal taxa in the Powder River were motile species, and the number of motile taxa appeared to increase in the downstream direction (table 6). Algal communities also were predominantly benthic forms (living on or attached to substrate). The relative abundance of benthic forms was 79 percent or more at all sites on the Powder River except at site PR9 below Dry Creek (49 percent; table 6) where sestonic (unattached) algae, primarily the blue-green algae Anabaena, composed 41 percent of the algal community.

Dominant taxa of blue-green algae included Phormidium, Leptolyngbya, and nitrogen-fixing Anabaena and Calothrix 
that can assimilate atmospheric nitrogen and become more common in waters where ratios of nitrogen to phosphorus are low (Porter, 2008). The relative abundances of nitrogen-fixers were highest at sites PR5 (45 percent), PR9 (38 percent), and PR17 (27 percent). The variability in relative abundance of nitrogen fixers among sites might be at least partially due to the colonial nature of blue-green algae, given that taxa richness of nitrogen fixers was low (0 to 3 taxa per site; table 6) and nitrogen-fixing diatoms (Rhopalodiaceae) composed less than 1 percent of relative abundance in the diatom community at each of the sites on the Powder River.

Powder River diatom communities were dominated by Nitzschia inconspicua, Navicula recens, and Nitzschia liebetruthii. Together, these three species composed more than 40 percent of the relative abundance of diatoms at every site on the Powder River (http://wy.water.usgs.gov/projects/atg/ htms/data.htm, accessed October 6, 2011). Nitzschia inconspicua is a facultative nitrogen heterotroph in streams of the central and western plains that can tolerate elevated nitrogen and phosphorus concentrations (Porter, 2008). Navicula recens is common to prairie creeks and large rivers of southeastern Montana characterized by elevated specific conductance $(3001 \mu \mathrm{S} / \mathrm{cm})$, alkalinity $(262 \mathrm{mg} / \mathrm{L})$, and turbidity (71 NTRU, nephelometric turbidity ratio units) (Bahls, 2005). Navicula recens also is considered a nutrient increaser, where relative abundance increases with increased nutrient concentrations (Teply and Bahls, 2005). Nitzschia liebetruthii is considered a general nutrient decreaser with a broad tolerance to nutrients although generally decreases with nutrient enrichment and high specific conductance (Bahls, 1993; Porter, 2008; and Teply and Bahls, 2005). Generally, the upper half of the Powder River study area, from sites PR1-PR11, exhibited the highest relative abundances of Nitzschia inconspicua and Navicula recens, which might reflect varying degrees of nutrient enrichment at those sites.

\section{Tongue River}

Tongue River algal communities were dominated by diatoms (average relative abundance 46 percent) and bluegreen algae (average 37 percent). Red algae ranged from 4 to 23 percent relative abundance and were represented entirely by Audouinella, an epiphyte on Cladophora that prefers fast water velocity (Blinn and Cole, 1991) (table 6). Green algae were uncommon in terms of relative abundance in the samples, though Cladophora were noted in riffles at all of the Tongue River sites.

Algal communities upstream of Tongue River Reservoir (sites TR1-TR4) were distinctly different from those downstream of the reservoir (sites TR5-TR6). Total richness averaged 70 taxa at sites TR1-TR4, compared to 38 taxa at sites TR5-TR6. Total richness increased from 57 taxa at site TR1 below Youngs Creek to 83 taxa at site TR2 above Prairie Dog Creek, then decreased to 71 taxa at site TR3 below Prairie Dog Creek and at site TR4 above Badger Creek (fig. 6). The
Shannon diversity index increased with distance downstream above the reservoir, from 0.96 at site TR1 to 1.42 at site TR4. The increase in algal taxa richness and diversity from site TR1 to TR2 was consistent with the increase in invertebrate community condition at those sites, but algal taxa richness and diversity did not appear to correspond with the decrease in invertebrate community condition from site TR3 to TR4.

The relative abundance of halophilic (high salinity conditions) diatoms ranged from 21 to 27 percent upstream of Tongue River Reservoir, compared to 55 to 59 percent downstream of the reservoir. Although specific conductance at the time of sampling was lower at sites TR5-TR6 than at sites TR1-TR4 (fig. 3), the higher abundance of halophilic diatoms downstream of the reservoir might be a reflection of waterquality conditions during other times of the year.

Organic nitrogen autotrophs were dominant, in terms of relative abundance, throughout the Tongue River, with minimal differences upstream and downstream of the reservoir (table 6). Alkaliphilic diatoms dominated at all of the sites on the Tongue River, with relative abundances of 63 to 72 percent at sites TR1-TR4, and 94 percent at sites TR5 and TR6. Alkabiontic diatoms, associated with higher $\mathrm{pH}$ than alkaliphilic diatoms, composed 26 percent of the diatom community at site TR1 and 19 percent at site TR2. The higher relative abundance of alkabiontic diatoms at sites TR1 and TR2 was not confirmed by $\mathrm{pH}$ measurements at the time of sampling (table 2) but might be an indicator of higher $\mathrm{pH}$ values during other times of the year.

Many algal taxa in the Tongue River were motile, representing 20 percent of the community in terms of relative abundance. Communities at sites TR1-TR4 contained 23 to 38 motile taxa, whereas sites TR5-TR6 contained 11 to 13 motile taxa (fig. 6). Motile taxa richness increased from 23 to 38 taxa between sites TR1 and TR2, then decreased to 30 taxa at site TR3 and 34 taxa at site TR4. The number of benthic taxa also was higher at sites TR1-TR4, ranging from 55 to 78 taxa, than at sites TR5-TR6, which had 33 to 35 benthic taxa.

The relative abundance of nitrogen-fixers was greatest at site TR1, below Youngs Creek (39 percent), and site TR6, below Hanging Woman Creek (19 percent), compared to less than 10 percent at other sites (table 6). Nostoc (blue-green algae) and the diatom Epithemia sorex were the most common nitrogen fixers (Porter, 2008) in the Tongue River. Epithemia sorex prefers a low ratio of nitrogen to phosphorus and often is associated with Cladophora and various nitrogen-fixing bluegreen algae (Bahls, 2005).

The dominant taxa, by relative abundance in the diatom communities of the Tongue River, were Epithemia sorex, Cocconeis pediculus, and Cocconeis placentula, particularly below Tongue River Reservoir (http://wy.water.usgs.gov/ projects/atg/htms/data.htm, accessed October 6, 2011). Epithemia sorex is often found in waters with moderate specific conductance $(752 \mu \mathrm{S} / \mathrm{cm})$, alkalinity $(226 \mathrm{mg} / \mathrm{L})$, and turbidity (23 NTRU) (Bahls, 2005). Cocconeis pediculus and Cocconeis placentula, both epiphytes on Cladophora, have similar 
Table 6. Algal community metrics for the Powder River and Tongue River, Wyoming and Montana, 2010.

[\%, percent; E, environmental; S, split; R, replicate]

\section{Taxa richness and abundance}

Diatom

community

metrics

\begin{tabular}{|c|c|c|c|c|c|c|c|c|c|c|c|}
\hline $\begin{array}{c}\text { Site } \\
\text { number }\end{array}$ & $\begin{array}{c}\text { Sample } \\
\text { date }\end{array}$ & $\begin{array}{c}\text { Algal taxa } \\
\text { richness }\end{array}$ & $\begin{array}{c}\text { Diatom } \\
\text { richness }\end{array}$ & $\begin{array}{c}\text { Diatom } \\
\text { abundance } \\
(\%)\end{array}$ & $\begin{array}{c}\text { Blue-green } \\
\text { algae } \\
\text { richness }\end{array}$ & $\begin{array}{c}\text { Blue- } \\
\text { green } \\
\text { algae } \\
\text { abundance } \\
\quad(\%)\end{array}$ & $\begin{array}{c}\text { Green } \\
\text { algae } \\
\text { richness }\end{array}$ & $\begin{array}{c}\text { Green } \\
\text { algae } \\
\text { abundance } \\
(\%)\end{array}$ & $\begin{array}{c}\text { Red } \\
\text { algae } \\
\text { richness }\end{array}$ & $\begin{array}{c}\text { Red } \\
\text { algae } \\
\text { abundance } \\
(\%)\end{array}$ & $\begin{array}{c}\text { Halophilic } \\
(\%)\end{array}$ \\
\hline
\end{tabular}

\begin{tabular}{|c|c|c|c|c|c|c|c|c|c|c|c|}
\hline \multicolumn{12}{|c|}{ Environmental samples } \\
\hline PR1 & $7 / 21 / 2010$ & 20 & 16 & 5 & 2 & 85 & 2 & 10 & 0 & 0 & 91 \\
\hline PR2 & $7 / 21 / 2010$ & 35 & 31 & 11 & 4 & 89 & 0 & 0 & 0 & 0 & 74 \\
\hline PR4 & $7 / 20 / 2010$ & 32 & 26 & 5 & 5 & 95 & 1 & 0 & 0 & 0 & 73 \\
\hline PR5 & $7 / 21 / 2010$ & 26 & 19 & 4 & 5 & 95 & 2 & 1 & 0 & 0 & 84 \\
\hline PR7 & $7 / 19 / 2010$ & 26 & 23 & 21 & 3 & 79 & 0 & 0 & 0 & 0 & 75 \\
\hline PR8 & $7 / 20 / 2010$ & 36 & 32 & 14 & 4 & 86 & 0 & 0 & 0 & 0 & 69 \\
\hline PR9 & $7 / 20 / 2010$ & 48 & 45 & 50 & 2 & 48 & 1 & 2 & 0 & 0 & 71 \\
\hline PR10 & $7 / 22 / 2010$ & 22 & 21 & 96 & 0 & 0 & 1 & 4 & 0 & 0 & 79 \\
\hline PR11 & $7 / 23 / 2010$ & 35 & 32 & 32 & 3 & 68 & 0 & 0 & 0 & 0 & 66 \\
\hline PR15 & $7 / 27 / 2010$ & 59 & 56 & 70 & 3 & 30 & 0 & 0 & 0 & 0 & 57 \\
\hline PR16 & $7 / 27 / 2010$ & 39 & 33 & 32 & 5 & 65 & 1 & 3 & 0 & 0 & 67 \\
\hline PR17 & $7 / 28 / 2010$ & 47 & 42 & 22 & 5 & 78 & 0 & 0 & 0 & 0 & 49 \\
\hline PR18 & $7 / 28 / 2010$ & 43 & 39 & 26 & 4 & 74 & 0 & 0 & 0 & 0 & 72 \\
\hline TR1 & $9 / 13 / 2010$ & 57 & 53 & 29 & 3 & 49 & 0 & 0 & 1 & 23 & 27 \\
\hline TR2 & $9 / 14 / 2010$ & 83 & 76 & 32 & 4 & 60 & 2 & 4 & 1 & 4 & 25 \\
\hline TR3 & $9 / 14 / 2010$ & 71 & 65 & 46 & 3 & 37 & 2 & 8 & 1 & 9 & 25 \\
\hline TR4 & $9 / 16 / 2010$ & 71 & 67 & 66 & 2 & 22 & 1 & 1 & 1 & 11 & 21 \\
\hline $\begin{array}{r}\text { PR12 sta } \\
\text { deviat }\end{array}$ & & 1.5 & 1.5 & 8.1 & .0 & 9.7 & .0 & 1.6 & .0 & .0 & 4.3 \\
\hline PR14E & $7 / 22 / 2010$ & 59 & 57 & 77 & 2 & 23 & 0 & 0 & 0 & 0 & 56 \\
\hline PR14S & $7 / 22 / 2010$ & 59 & 56 & 69 & 2 & 31 & 1 & 0 & 0 & 0 & 53 \\
\hline $\begin{array}{r}\text { PR14 sta } \\
\text { deviati }\end{array}$ & & 0.0 & .7 & 5.7 & .0 & 5.4 & .7 & .2 & .0 & .0 & 1.9 \\
\hline
\end{tabular}


Table 6. Algal community metrics for the Powder River and Tongue River, Wyoming and Montana, 2010.—Continued $[\%$, percent; E, environmental; S, split; R, replicate $]$

\begin{tabular}{|c|c|c|c|c|c|c|c|c|c|c|c|c|}
\hline \multicolumn{2}{|c|}{$\begin{array}{c}\text { Diatom } \\
\text { community } \\
\text { metrics }\end{array}$} & \multicolumn{7}{|c|}{ Diatom community metrics } & \multicolumn{4}{|c|}{ Algal community metrics } \\
\hline $\begin{array}{c}\text { Nitrogen } \\
\text { autotrophs } \\
(\%)\end{array}$ & $\begin{array}{c}\text { Facul- } \\
\text { tative } \\
\text { nitrogen } \\
\text { hetero- } \\
\text { trophs } \\
(\%)\end{array}$ & $\begin{array}{c}\text { Obligate } \\
\text { nitrogen } \\
\text { hetero- } \\
\text { trophs } \\
(\%)\end{array}$ & $\begin{array}{c}\text { Circum- } \\
\text { neutral } \\
\text { pH } \\
(\%)\end{array}$ & $\begin{array}{c}\text { Alkali- } \\
\text { philic } \\
(\%)\end{array}$ & $\begin{array}{c}\text { Alka- } \\
\text { biontic } \\
(\%)\end{array}$ & $\begin{array}{l}\text { Shannon } \\
\text { diversity } \\
\text { index }\end{array}$ & $\begin{array}{l}\text { Motile } \\
\text { taxa } \\
\text { richness }\end{array}$ & $\begin{array}{l}\text { Motile } \\
\text { abun- } \\
\text { dance } \\
(\%)\end{array}$ & $\begin{array}{l}\text { Benthic } \\
\text { taxa } \\
\text { richness }\end{array}$ & $\begin{array}{l}\text { Benthic } \\
\text { abun- } \\
\text { dance } \\
(\%)\end{array}$ & $\begin{array}{l}\text { Nitrogen } \\
\text { fixer } \\
\text { taxa } \\
\text { richness }\end{array}$ & $\begin{array}{c}\text { Nitrogen } \\
\text { fixers } \\
(\%)\end{array}$ \\
\hline \multicolumn{13}{|c|}{ Environmental samples } \\
\hline 5 & 94 & 2 & 2 & 97 & 0 & 0.42 & 9 & 19 & 20 & 100 & 0 & 0 \\
\hline 24 & 72 & 4 & 1 & 93 & 6 & .61 & 18 & 65 & 32 & 98 & 2 & 2 \\
\hline 18 & 81 & 1 & 1 & 99 & 0 & .36 & 12 & 79 & 19 & 99 & 2 & 16 \\
\hline 25 & 69 & 6 & 3 & 96 & 1 & .67 & 13 & 40 & 24 & 100 & 0 & 0 \\
\hline 26 & 68 & 6 & 4 & 94 & 1 & .57 & 20 & 81 & 33 & 93 & 3 & 10 \\
\hline 28 & 65 & 7 & 11 & 83 & 4 & .96 & 30 & 43 & 44 & 49 & 2 & 38 \\
\hline 21 & 74 & 5 & 4 & 96 & 0 & .79 & 15 & 86 & 20 & 100 & 0 & 0 \\
\hline 34 & 60 & 7 & 13 & 85 & 1 & .65 & 15 & 24 & 30 & 99 & 1 & 1 \\
\hline 61 & 36 & 3 & 5 & 93 & 2 & .89 & 17 & 27 & 26 & 99 & 0 & 0 \\
\hline 27 & 50 & 23 & 11 & 88 & 1 & 1.20 & 26 & 61 & 42 & 79 & 1 & 15 \\
\hline 33 & 50 & 16 & 14 & 81 & 2 & 1.25 & 37 & 80 & 56 & 93 & 0 & 0 \\
\hline 25 & 51 & 24 & 17 & 77 & 1 & 1.25 & 37 & 58 & 55 & 95 & 2 & 3 \\
\hline 85 & 5 & 10 & 15 & 63 & 4 & 1.42 & 34 & 41 & 68 & 99 & 2 & 2 \\
\hline 98 & 1 & 1 & 3 & 94 & 2 & .91 & 11 & 23 & 33 & 93 & 3 & 6 \\
\hline 100 & 0 & 0 & 1 & 94 & 4 & .99 & 13 & 6 & 35 & 82 & 3 & 19 \\
\hline \multicolumn{13}{|c|}{ Standard deviation among metrics from environmental, split, and replicate samples } \\
\hline 61 & 36 & 3 & 5 & 93 & 2 & 0.89 & 17 & 27 & 26 & 99 & 0 & 0 \\
\hline 59 & 37 & 4 & 4 & 94 & 2 & 0.70 & 17 & 28 & 27 & 99 & 0 & 0 \\
\hline 66 & 26 & 7 & 3 & 95 & 2 & 0.89 & 17 & 37 & 30 & 100 & 0 & 0 \\
\hline 3.8 & 6.0 & 2.3 & .8 & .7 & .2 & 0.11 & .0 & 5.2 & 2.1 & .5 & .0 & 0 \\
\hline 33 & 50 & 16 & 14 & 81 & 2 & 1.25 & 37 & 80 & 56 & 93 & 0 & 0 \\
\hline 29 & 52 & 19 & 16 & 80 & 2 & 1.24 & 34 & 79 & 55 & 95 & 1 & 0 \\
\hline 3.0 & 1.1 & 1.9 & 1.5 & .4 & .0 & .01 & 2.1 & .3 & .7 & 1.1 & .7 & 0 \\
\hline
\end{tabular}



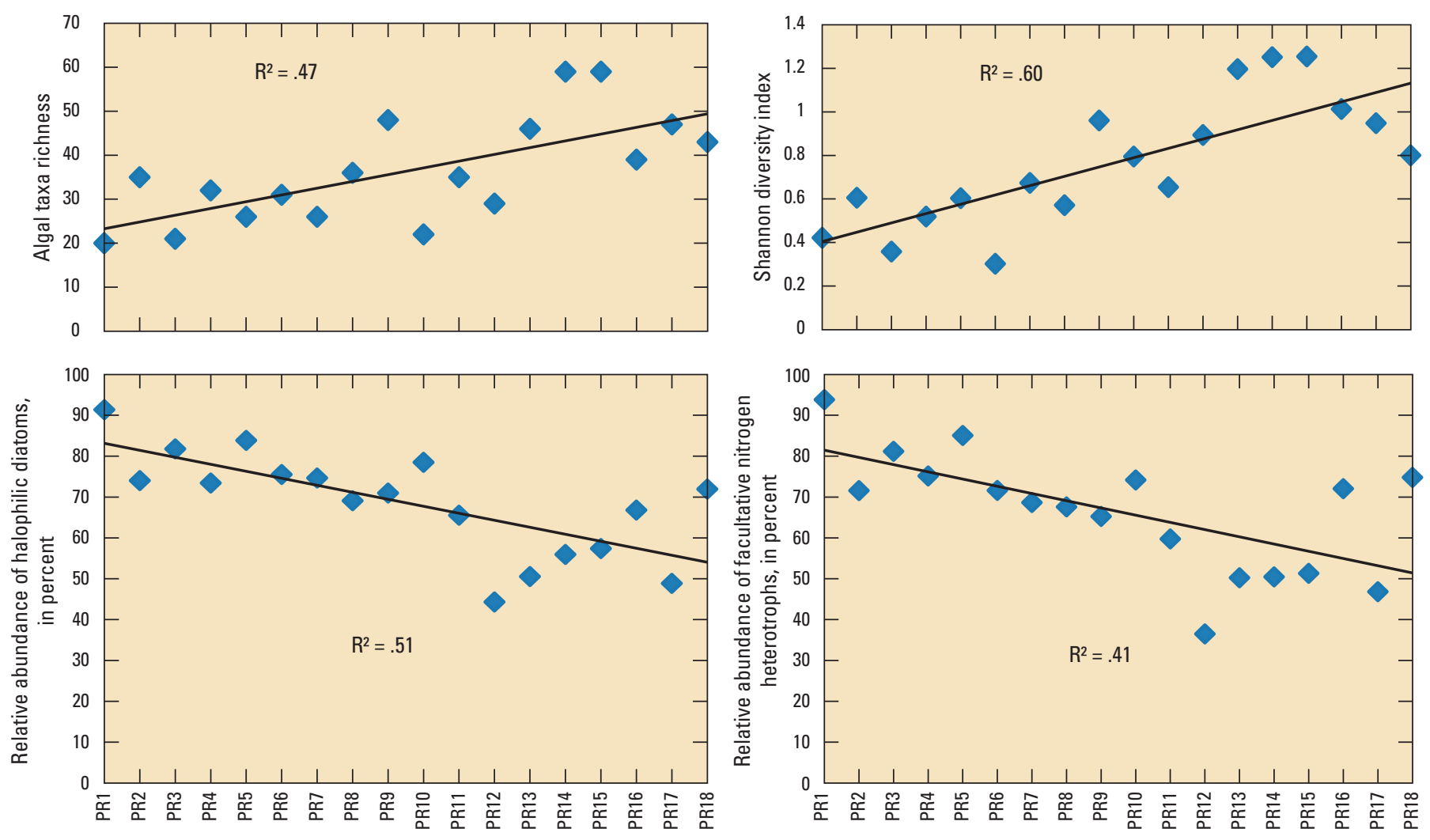

Powder River site number

Powder River site number
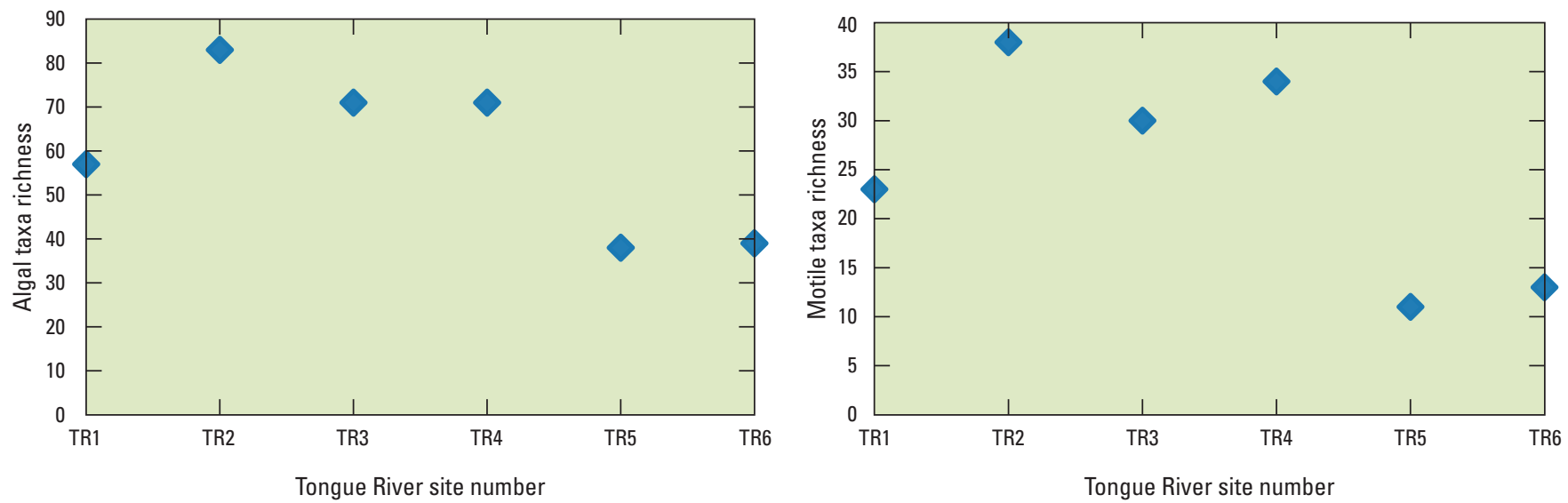

Figure 6. Algal community metrics for ecological sampling sites on the Powder River and Tongue River, Wyoming and Montana, 2010. 
water-quality preferences as Epithemia sorex (Bahls, 2004). The presence and relative abundance of these three taxa in the Tongue River coincided with their expected water-quality affinities.

\section{Potential Effects of Water Produced from Coalbed Natural Gas Development on Biological Communities}

The ecological data presented in this report were collected to assess conditions in the Powder River and Tongue River upstream and downstream of known CBNG effluent discharges that enter the rivers directly or via tributaries (table 1), with the exception of sites TR5-TR6 that were sampled as a baseline for future development. Toxicity of CBNG effluents to aquatic life due to elevated sodium bicarbonate concentrations has been described in laboratory toxicity tests and in mixing zones within the Tongue River (Parkhurst, 2010; Pillard, 2010) and from the Powder River (Farag and others, 2010).

Samples of major ions collected in conjunction with the biological samples during this study indicated alkalinity concentrations were similar in the Tongue River and Powder River, ranging from 162 to $305 \mathrm{mg} / \mathrm{L}$ as $\mathrm{CaCO}_{3}$ (table 2). Alkalinity concentrations were highest at sites PR10-PR12 (fig. 3). Maximum alkalinity concentrations in the Powder River during 2010 were lower than maximum concentrations during 2005-08 (Peterson and others, 2010), perhaps due to effects of dilution of CBNG effluents by higher streamflow in 2010. Maximum alkalinity concentrations during 2005-2008 exceeded $1,000 \mathrm{mg} / \mathrm{L}$ and also exceeded the $625-\mathrm{mg} / \mathrm{L}$ sodium bicarbonate concentration associated with reduced survival of fathead minnows (Farag and others, 2010). Given that alkalinity and sodium concentrations in this report are reported individually, it is beyond the scope of this report to compute potential toxicity during 2010 . Also, it should be noted that biological communities reflect water-quality conditions over a longer time period than captured in instantaneous waterquality samples and thereby act as integrators of water quality prior to the sampling events.

\section{Powder River}

The Powder River was divided into three zones for the purposes of discussion. The upper reaches include sites PR1-PR9, the middle reaches include sites PR9-PR14, and the lower reaches include sites PR14-PR18.

Within the upper reaches of the Powder River, macroinvertebrate communities indicated significant differences $(p<0.05)$ between site pairs designed to bracket CBNG effluents and tributaries (table 1). Potential increases in condition of the macroinvertebrate community were evident at three of the site pairs: from upstream to downstream of Dry Fork and Willow Creeks (sites PR1-PR2), Beaver Creek (sites PR5-PR6), and Dry Creek (sites PR8-PR9). The determination of increase in biological condition was based on several groups of metrics including functional feeding groups, community composition, and dominant taxon or diversity (table 4). Conversely, the macroinvertebrate metrics indicated a decline in biological condition from sites PR2 to PR3. Although sites PR2 and PR3 were not designed as a site pair, a relatively large number of metrics (13) were significantly $(p<0.05)$ different between sites PR2 and PR3 and indicated the negative effects of an unidentified influence on the macroinvertebrate communities. No significant differences in macroinvertebrate metrics were noted at site pairs upstream and downstream of Pumpkin Creek (sites PR3-PR4), Fourmile Creek (sites PR4-PR5), and Burger Draw (sites PR6-PR7).

The O/E scores for the upper reaches of the Powder were spatially variable and indicated some localized spatial patterns similar to those indicated by the macroinvertebrate metrics, such as increases in biological condition from sites PR1 to PR2 and PR5 to PR6, and a significant decrease at sites PR2 to PR3. The variable but overall decline in $\mathrm{O} / \mathrm{E}$ scores in the PR2-PR9 segment indicates localized noncumulative environmental stressors influenced the macroinvertebrate communities in 2010.

Algal community metrics in the upper reaches of the Powder River generally supported the macroinvertebrate results. For example, algal taxa richness and Shannon diversity increased at sites PR1-PR2, PR5-PR6, and PR8-PR9, with the exception of a decrease in diversity at sites PR5-PR6, whereas algal taxa richness and diversity decreased from sites PR2 to PR3, concurrent with the decline in biological condition noted from the macroinvertebrate results.

Macroinvertebrate community metrics indicated potential decline in biological condition in the middle reaches of the Powder River (sites PR9-PR14). Functional feeding groups, community composition, tolerance, and diversity or dominant taxon indicated declines at designated site pairs upstream and downstream of Flying E Creek (sites PR9-PR10) and Wild Horse Creek (sites PR13-PR14), as well as at sites PR12-PR13 that were not a designated site pair. The decline between sites PR12 and PR13 might be associated with the inflow from Crazy Woman Creek (streamgage 06316400) and other sources as described earlier in this report. No significant differences in macroinvertebrate metrics were noted at site pairs upstream and downstream of Barber Creek (sites PR10-PR11), and other effluents (sites PR11-PR12).

Macroinvertebrate $\mathrm{O} / \mathrm{E}$ scores in the middle reaches of the Powder River indicated substantial decline in biological condition from site PR10 to PR14. The declining trend indicates the macroinvertebrate communities were subjected to cumulative effects of environmental stressors with distance downstream.

Algal community metrics supported the macroinvertebrate community decline at sites PR9-PR10, as indicated by 
decreases in algal taxa richness and diversity, and increases in relative abundance of halophilic and nitrogen heterotrophic diatoms. Obligate nitrogen heterotrophs, which need continuously elevated concentrations of organic nitrogen, composed less than 10 percent of the diatoms in the Powder River except at sites PR13-PR15 where they composed 16 to 24 percent. The increase in obligate nitrogen heterotrophs indicates the influx of water between sites PR12 and PR13 might have contained high concentrations of organic nitrogen.

Macroinvertebrate communities in the lower reaches of the Powder River indicated an increase in biological condition from upstream to downstream of CBNG effluents (sites PR14-PR15) and SA Creek (sites PR17-PR18). A relatively large number (13) of metrics were significantly different $(\mathrm{p}<0.05)$ between sites PR14 and PR15, including increases in total richness, diversity, and relative abundance of Ephemeroptera, intolerant macroinvertebrates, and collectorgatherers. Four macroinvertebrate metrics were significantly different between sites PR17 and PR18, including increases in relative abundance of Ephemeroptera and Chironomidae, and decreases in filterer-collectors and density. No significant differences in metrics were noted from upstream to downstream of LX Bar Creek (sites PR16-PR17).

The O/E scores in the lower reaches of the Powder River indicated a substantial increase in biological condition from sites PR14 to PR15, and a slight decrease from site PR15 to PR17. The O/E scores increased from site PR17 to PR18, indicating an increased biological condition similar to that noted in the macroinvertebrate metric results.

Algal communities of the lower Powder River were marked by maximum values of taxa richness and diversity at sites PR14 and PR15. Relative abundance of halophilic diatoms increased upstream to downstream of SA Creek, coincident with the increase in biological condition noted in the macroinvertebrate communities. The algal community below LX Bar Creek contained a higher percentage of circumneutral diatoms preferring neutral $\mathrm{pH}$ than any of the sites on the Powder River that were dominated by alkaliphilic diatoms that prefer alkaline $\mathrm{pH}$ values, which may indicate contributions of less alkaline water.

Comparison of the 2010 macroinvertebrate communities with those sampled in 2005-08 indicated potential temporal changes in biological condition in the upper reaches of the Powder River (fig. 7). The 2005-08 metrics shown in figure 7 had significant differences in the middle reaches compared to upper and lower reaches, such as the low relative abundance of intolerant macroinvertebrates from river miles 283 to 406 (Peterson and others, 2010). The mean values of metrics during 2010 also indicated decreased biological condition in the middle reaches of the Powder River; however, the 2010 change in biological condition occurred at river mile 351, downstream of the 2005-08 point of change, potentially indicating an increase in biological condition in the vicinity of river miles 283 to 351 . Changes in the amounts or quality of CBNG effluents in the upper reaches of the Powder River might account for differences between the 2005-08 and
2010 results. Biological condition in the lower Powder River increased at river mile 243 during 2005-08 and again at the same point in 2010 .

\section{Tongue River}

Macroinvertebrate community metrics for the Tongue River generally indicated an increase in biological condition from site TR1, near the Wyoming-Montana border, to site TR2, downstream of some of the CBNG-produced water discharges in Montana. Sites TR2 and TR3, upstream and downstream of Prairie Dog Creek which receives CBNG and irrigation discharges, had relatively few significant differences in macroinvertebrate metric values. Several macroinvertebrate community metrics indicated a decline in biological condition from site TR3 to site TR4, which are upstream and downstream respectively of CBNG production water discharges between Prairie Dog Creek and Badger Creek.

The $\mathrm{O} / \mathrm{E}$ and $\mathrm{BC}$ scores for the macroinvertebrate community at site TR1 were significantly different $(p<0.05)$ from those calculated for sites TR2, TR3, and TR4. The model scores calculated from the samples collected from TR5 and TR6 were not significantly different from any of the other sites but were slightly closer to the expected reference condition than TR1 that had the lowest score among the Tongue River sites. The scores calculated from site TR3 samples were highest, and therefore closest to the expected condition.

Algal community metrics in the Tongue River indicated an increase in total richness and motile taxa richness from site TR1 to TR2, consistent with the increase in biological condition noted from the macroinvertebrate metrics. Site TR1 was notable for high relative abundances of nitrogen-fixing algae and alkabiontic (high $\mathrm{pH}$ ) diatoms. Algal metrics at site pairs TR2 to TR3 and TR3 to T4 did not appear to change substantially between the sites.

\section{Further Study Needs}

The 2010 sampling at site pairs upstream and downstream of CBNG effluents identified specific points where changes in biological condition occurred, in addition to confirming the results from 2005-08. Confirmation of the changes in condition at specific sites would be beneficial. For example, the maximum alkalinity concentrations in the Powder River coincided with a reach of declining biological condition, but not all site pairs with declines in biological condition had high alkalinity concentrations. Biological communities are long-term indicators of water-quality change, as they integrate responses to both natural and anthropogenic influences over time. Given that this is the first year of sampling focused on the effect on the mainstem biota from the tributaries, additional continued monitoring of macroinvertebrates, algae, and water quality, including nutrients, would provide further resolution to the spatial and general temporal patterns identified with this and previous studies. 

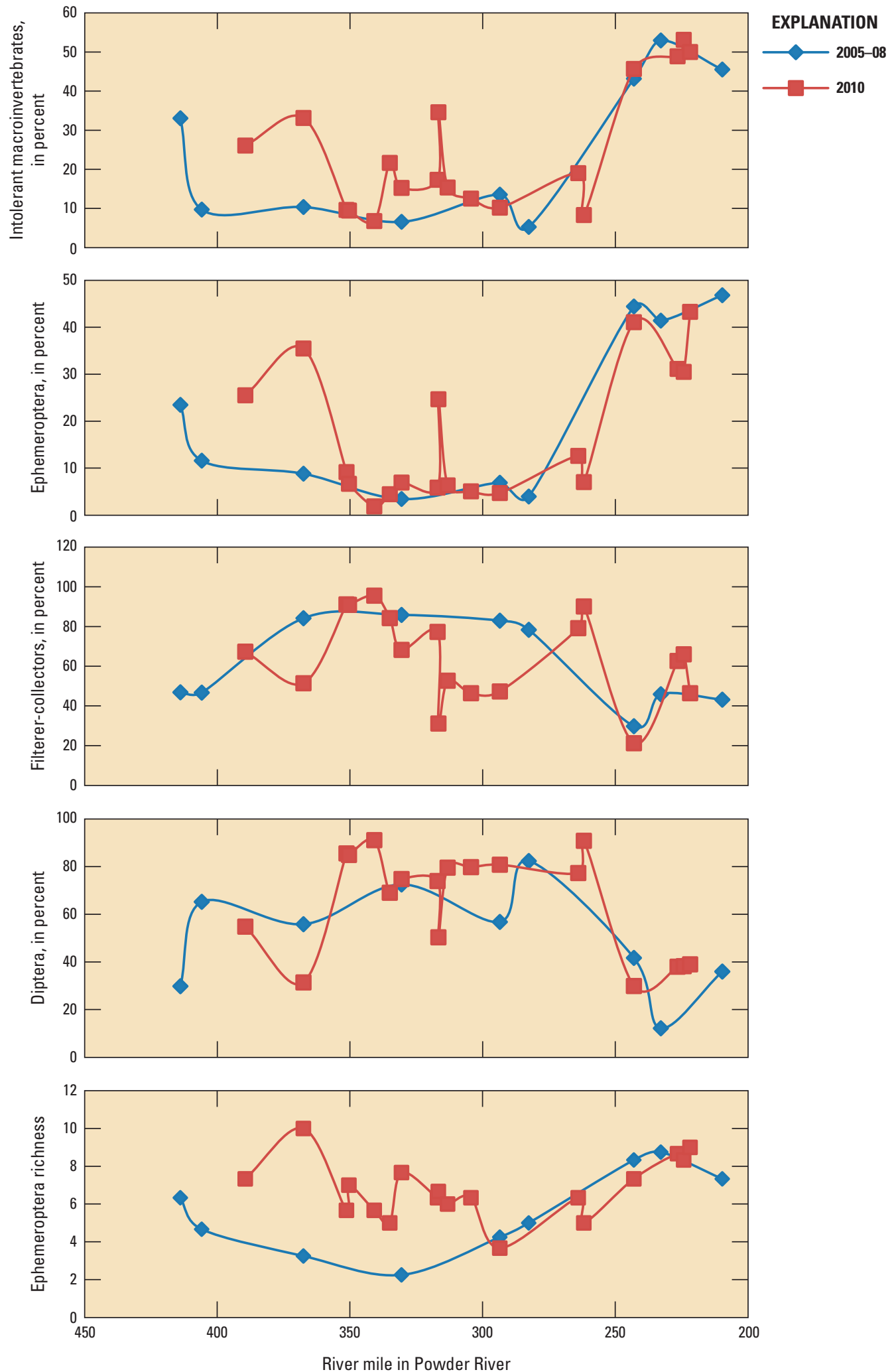

Figure 7. Comparison of mean macroinvertebrate metric scores from 2005-08 to mean scores from 2010, Powder River, Wyoming. 


\section{Summary}

Ongoing development of coalbed natural gas in the Powder River structural basin in Wyoming and Montana led to formation of an interagency task group, and a subgroup, the Aquatic Task Group (ATG), to address concerns about the effects of the resulting production water on biological communities in streams of the area. This study was conducted under the direction of the ATG, and in cooperation with the Bureau of Land Management, the Montana Department of Environmental Quality, the Wyoming Department of Environmental Quality, and the Wyoming Game and Fish Department. Samples of macroinvertebrates, algae, water quality, and related measurements were collected at 18 sites on the mainstem Powder River and 6 sites on the mainstem Tongue River in 2010. Sampling-site locations were selected on a paired approach, typically upstream and downstream of direct discharge points and tributaries associated with coalbed natural gas development.

Differences in biological condition among site pairs were evaluated using multiple lines of evidence including macroinvertebrate and algal community metrics and observed/ expected $(\mathrm{O} / \mathrm{E})$ macroinvertebrate models. Triplicate samples of macroinvertebrates were used to test for statistically significant differences among site pairs using metrics including taxa richness, taxa relative abundance, functional feeding groups, and tolerance, as well as $\mathrm{O} / \mathrm{E}$ scores.

The Powder River was divided into three zones for the purposes of discussion. The upper reach includes sites PR1-PR9, the middle reach includes sites PR9-PR14, and the lower reach includes sites PR14-PR18. Biological condition in the upper reach of the Powder River was spatially variable, but the multiple lines of evidence generally agreed about the indication of increase or decrease at given site pairs. Invertebrate community metrics and $\mathrm{O} / \mathrm{E}$ scores, as well as algal metrics, indicated a substantial decline in biological condition between sites PR2 and PR3, from downstream of Willow Creek to upstream of Pumpkin Creek. At other site pairs, multiple lines of evidence indicate no significant differences or an increase in biological condition, such as an increase between sites PR5 and PR6, upstream and downstream of Beaver Creek. The spatial variability indicates localized noncumulative stressors might be affecting the biota. Biological condition, as indicated by macroinvertebrate metrics and $\mathrm{O} / \mathrm{E}$ scores and algal metrics, generally declined in the middle reaches of the Powder River, indicating potential cumulative effects from CBNG discharges in some of the reaches from Flying E Creek to downstream of Wild Horse Creek. The middle reaches of the Powder River also contained the highest alkalinity concentrations, a potential indicator of toxicity from sodium bicarbonate. Inflow of water between sites PR12 and PR13, between Barber Creek and Wild Horse Creek, might be associated with the corresponding decline in macroinvertebrate community condition and increase in facultative nitrogen heterotrophic diatoms. The increase in nitrogen heterotrophs indicates that the water contains relatively high concentrations of organic nitrogen. Comparison of invertebrate metric results from 2010 to those from 2005-08 corroborated previous findings (Peterson and others, 2010) that biological condition in the middle reaches of the Powder was lower than in the upper or lower reaches. Mean $\mathrm{O} / \mathrm{E}$ scores in the middle reaches were as low as 0.37 , indicating substantially decreased biological condition compared to the reference condition score of 1.00 .

Biological condition in the lower reaches of the Powder River was variable, indicating declines at some site pairs and no significant differences or increases at others. The 2010 macroinvertebrate metrics, $\mathrm{O} / \mathrm{E}$ scores, and algal metrics indicated a substantial increase in biological condition from site PR14 to PR15, which is the same reach where biological condition increased during 2005-08.

Biological condition at site pairs on the Tongue River showed an increase in one case, near the Wyoming-Montana border, and a decrease in another case, near Badger Creek. Few significant differences were noted from upstream to downstream of Prairie Dog Creek, a major tributary. No significant differences were noted in the Tongue River upstream and downstream of Hanging Woman Creek, a site pair related to potential development in the Hanging Woman Creek drainage.

Further study would be beneficial to confirm the patterns observed, including increases and decreases in biological condition. An additional year of sampling at the same sites also will help pinpoint areas of interest to examine in greater detail.

\section{Acknowledgments}

David Mott, Greg Boughton, Scott Edmiston, Clint Masters, and Seth Davidson of the USGS, as well as several interns from the BLM, assisted with data collection in 2010. Many private landowners and the Anadarko Corporation (The Woodlands, Texas), allowed access to sampling sites. Colleague reviewers were Kathy Foster and Jill Frankforter.

\section{References}

Bahls, L.L., 1993, Periphyton bioassessment methods for Montana streams: Helena, Mont., Montana Department of Environmental Quality, 31 p. plus appendixes.

Bahls, L.L., 2004, Northwest diatoms-A photographic catalogue of species in the Montana diatom collection with ecological optima, associates, and distribution records for the nine northwestern United States: Helena, Mont., copyright Loren L. Bahls, v. 1, approx. 150 p.

Bahls, L.L., 2005, Northwest diatoms-A photographic catalogue of species in the Montana diatom collection with ecological optima, associates, and distribution records for the nine northwestern United States: Helena, Mont., copyright Loren L. Bahls, v. 2, approx. 300 p. 
Barbour, M.T., Gerritsen, J., Snyder, B.D., and Stribling, J.B., 1999, Rapid bioassessment protocols for use in streams and wadeable rivers - Periphyton, benthic macroinvertebrates, and fish: U.S. Environmental Protection Agency, Office of Water, [report] EPA 841-B-99-002, 2d ed., variable pagination.

Blinn, D.W., and Cole, G.A., 1991, Algal and invertebrate biota in the Colorado River-Comparison of pre- and postdam conditions, in Colorado River Ecology and Dam Management_-Proceedings of a Symposium: Sante Fe, N. Mex., May 24-25, 1990, National Academies Press, 276 p.

Bray, J.R., and Curtis, J.T., 1957, An ordination of the upland forest communities of southern Wisconsin: Ecological Monographs, v. 27, p. 325-349.

Bureau of Land Management, U.S. Department of the Interior, 2003, Record of decision and resource management plan amendments for the Powder River Basin oil and gas project: U.S. Department of the Interior Bureau of Land Management, Buffalo Field Office, Wyo., April 2003, WY-07002-065 [variously paginated], accessed February 16, 2010, at http://www.blm.gov/pgdata/etc/media-lib/blm/wy/ information/NEPA/prb-rod.Par.71614.File.dat/00rod.pdf.

Bureau of Land Management, U.S. Department of the Interior, 2009, Powder River Basin Interagency Working Group, U.S. Department of the Interior Bureau of Land Management, accessed on September 21, 2009, at http://www. wy.blm.gov/prbgroup/.

Clarke, R.T., Wright, J.F., and Furse, M.T., 2003, RIVPACS models for predicting the expected macroinvertebrate fauna and assessing the ecological quality of rivers: Ecological Modeling, v. 160, p. 219-233.

Cuffney, T.C., 2003, User's manual for the National WaterQuality Assessment Program invertebrate data analysis system (IDAS) software-Version 3: U.S. Geological Survey Open-File Report 2003-172, 103 p.

Davis, W.N., 2008, Effects of coalbed natural gas development on fish assemblages in tributary streams in Powder River Basin, Montana and Wyoming: Bozeman, Montana State University, Master's thesis, 137 p., 26 figs.

Davis, W.N., Bramblett, R.G., Zale, A.V., and Endicott, C.L., 2009 , A review of the potential effects of coal bed natural gas development activities on fish assemblages of the Powder River geologic basin: Reviews in Fisheries Science, v. 17 , no. 3 , p. $402-422$.

Elliott, A.G., Hubert, W.A., and Anderson, S.H., 1997, Habitat associations and effects of urbanization on macroinvertebrates of a small, high-plains stream: Journal of Freshwater Ecology, v. 12, p. 61-73.
Farag, A.M., Harper, D.D., Senecal, Anna, and Hubert, W.A., 2010, Potential effects of coalbed natural gas development on fish and aquatic resources, in Reddy, K.J., ed., Coalbed Natural Gas-Energy and Environment: New York, Nova Science Publishers, p. 227-242.

Gray, L.J., and Ward, J.V., 1982, Effects of sediment releases from a reservoir on stream macroinvertebrates: Hydrobiologia, v. 96, p. 177-184.

Grime, J.P., 1973, Control of species density in herbaceous vegetation: Journal of Environmental Management, v. 1, p. 151-167.

Hargett, E.G., Zumberge, J.R., Hawkins, C.P., and Olson, J.R., 2007, Development of a RIVPACS-type predictive model for bioassessment of wadeable streams in Wyoming: Ecological Indicators, v. 7, p. 807-826.

Hargett, E.G., Zumberge, J.R., and Hawkins, C.P., 2005, Development of a RIVPACS model for wadeable streams of Wyoming: Wyoming Department of Environmental Quality, Water Quality Division Report, 64 p.

Helsel, D.R., and Hirsch, R.M., 2002, Statistical methods in water resources: U.S. Geological Survey Techniques of Water Resources Investigations, book 4, chap. A3, 522 p.

Hilsenhoff, W.L., 1987, An improved index of organic stream pollution: Great Lakes Entomologist, v. 20, p. 31-39.

Merritt, R.W., and Cummins, K.W., 1996, An introduction to the aquatic insects of North America: Dubuque, Iowa, Kendall/Hunt Publishing Co., 3rd ed., 862 p.

Montana Department of Environmental Quality, 2006, Sample collection, sorting, and taxonomic identification of benthic macroinvertebrates: Montana Department of Environmental Quality, Water Quality Planning Bureau, Standard Operating Procedure WQPBWQM-009, 32 p.

Moss, D., Furse, M.T., Wright, J.F., and Armitage, P.D., 1987, The prediction of the macroinvertebrate fauna of unpolluted running water sites in Great Britain using environmental data: Freshwater Biology, v. 17, p. 41-52.

Moulton, S.R., II, Kennen, J.G., Goldstein, R.M., and Hambrook, J.A., 2002, Revised protocols for sampling algal, invertebrate, and fish communities as part of the National Water-Quality Assessment Program: U.S. Geological Survey Open-File Report 2002-150, 75 p.

Parkhurst, B., 2010, Do discharges of coalbed natural gas water cause impacts to benthic life in the Tongue River, Montana, in Conference on Energy Resources and Produced Waters - Water Quality, Management, Treatment, and Use: Laramie, Wyo., May 25-26, 2010, University of Wyoming, slide presentation, accessed December 16, 2011, at http:// www.uwyo.edu/enr/ruckelshaus-institute/projects-andevents/pwc.html. 
Pillard, D., 2010, Toxicity identification evaluation studies to determine the cause of laboratory whole effluent toxicity to Ceriodaphnia dubia from produced water, in Conference on Energy Resources and Produced Waters-Water Quality, Management, Treatment, and Use: Laramie, Wyo., May 25-26, 2010, University of Wyoming, slide presentation, accessed December 16, 2011, at http://www.uwyo.edu/ enr/ruckelshaus-institute/projects-and-events/pwc.html.

Peterson, D.A., 1990, Invertebrate communities of small streams in northeastern Wyoming: U.S. Geological Survey, Water-Resources Investigations Report 85-4287, 45 p.

Peterson, D.A., Wright, P.R., Edwards, G.P., Jr., Hargett, E.G., Feldman, D.L., Zumberge, J.R., and Dey, Paul, 2009, Ecological assessment of streams in the Powder River structural basin, Wyoming and Montana, 2005-06: U.S. Geological Survey Scientific Investigations Report 2009-5023, 139 p.

Peterson, D.A., Clark, M.L., Foster, Katharine, Wright, P.R., and Boughton, G.K., 2010, Assessment of ecological conditions and potential effects of water produced from coalbed natural gas development on biological communities in streams of the Powder River structural basin, Wyoming and Montana, 2005-08: U.S. Geological Survey Scientific Investigations Report 2010-5124, 84 p.

Porter, S.D., 2008, Algal attributes-An autecological classification of algal taxa collected by the National WaterQuality Assessment Program: U.S. Geological Survey Data Series 329, 18 p., accessed October 2011, at http://pubs. usgs.gov/ds/ds329.

Powder River Natural Gas Interagency Working Group, 2004, Charter: U.S. Department of the Interior Bureau of Land Management, Buffalo, Wyo., 15 p., accessed April 1, 2008, at http://www.wy.blm.gov/prbgroup/pdfs/charter061504.pdf.

Rantz, S.E., and others, 1982, Measurement and computation of streamflow: U.S.Geological Survey Water-Supply Paper 2175, 2 v., 631 p. [Additional contributors are listed under Acknowledgments.]

Rice, C.A., Ellis, M.S., and Bullock, J.H., Jr., 2000, Water coproduced with coalbed methane in the Powder River Basin, Wyoming_-Preliminary compositional data: U.S. Geological Survey Open-File Report 2000-372, 20 p.

Ringen, B.H., and Daddow, P.B., 1990, Hydrology of the Powder River alluvium between Sussex, Wyoming, and Moorhead, Montana: U.S. Geological Survey Water-Resources Investigations Report 89-4002, 48 p.
Skaar, Don, Farag, A.M., and Harper, D., 2006, Toxicity of sodium bicarbonate to fish from coal-bed natural gas production in the Tongue and Powder River drainages, Montana and Wyoming: U.S. Geological Survey Fact Sheet 2006-3092, 4 p.

Teply, Mark, and Bahls, L.L., 2005, Diatom biocriteria for Montana streams, 2005: Helena, Montana Dept. of Environmental Quality, 22 p.

TIBCO, 2008, Tibco Spotfire S+, version 8.1.1: Palo Alto, Calif., TIBCO Software, Inc., unpaginated.

U.S. Geological Survey, variously dated, National field manual for the collection of water-quality data: U.S. Geological Survey Techniques of Water-Resources Investigations, book 9, chaps. A1-A9, available online at http://pubs.water. usgs.gov/twri9A, accessed September 2011.

Van Dam, H., Mertens, A., and Sinkeldam, J., 1994, A coded checklist and ecological indicator values of freshwater diatoms from the Netherlands: Netherlands Journal of Aquatic Ecology, v. 28, no. 1, p. 117-133.

Van Sickle, J. 2008, An index of compositional dissimilarity between observed and expected assemblages: Journal of the North American Benthological Society, v. 27, no. 2, p. 227-235.

Ward, J.V., 1992, Aquatic Insect Ecology 1-Biology and Habitat: John Wiley \& Sons, Inc., 438 p.

Ward, J.V., 1986, Altitudinal zonation in a Rocky Mountain stream: Archives of Hydrobiologia, Supplement 74, p. 133-199.

Winget, R.N., and Mangum, F.A., 1991, Environmental profile of Tricorythodes minutus Traver (Ephemeroptera: Ephemerellidae) in the western United States: Journal of Freshwater Ecology, v. 6, p. 335-344.

Wolman, M.G., 1954, A method for sampling coarse riverbed material: Transactions of the American Geophysical Union, v. 35, p. 951-956.

Wright, J.F., Furse, M.T., and Armitage, P.D., 1993, RIVPACS - A technique for evaluating the biological quality of rivers in the U.K.: European Water Pollution Control, v. 3, p. 15-25.

Zar, J.H., 1984, Biostatistical Analysis: Englewood Cliffs, N.J., Prentice Hall, 2nd ed., 718 p. 
Publishing support provided by the:

Rolla and Denver Publishing Service Centers

For more information concerning this publication, contact: Director, Wyoming Water Science Center

U.S. Geological Survey

521 Progress Circle, Suite 6

Cheyenne, Wyoming 82007

(307) 778-2931

Or visit the Wyoming Water Science Center Web site at: http://wy.water.usgs.gov/ 


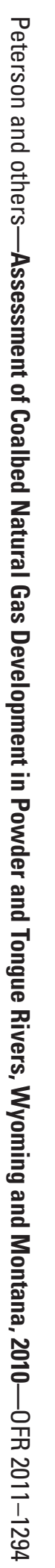

